\title{
»Nordschleswig Erwache!!!«
}

\section{Det tyske mindretal og nazismen i 1933}

\author{
af HeNRIK BeCKer-Christensen
}

For det tyske mindretal i Nordslesvig blev den nazistiske magtovertagelse $\mathbf{i}$ Tyskland i 1933 indledningen til et nyt kapitel. Den gamle ledelse med pastor Schmidt-Vodder i spidsen søgte tøvende at fastholde en vis selvstændighed, men yngre kræfter lod sig straks begejstre. Efter indgående kildestudier belyser direktør, dr.phil. Henrik Becker-Christensen, Aabenraa, her mindretallets reaktioner overfor den nye bevægelse sydfra og oprettelsen af det forste tysknazistiske parti NSAN i 1933.

\section{Systemskiftet i Tyskland}

Det var ved rigsdagsvalget i september 1930, at Adolf Hitlers Nationalsozialistische Deutsche Arbeiterpartei - i forkortet form NSDAP fik sit politiske gennembrud. Fra en skyggetilværelse blev det med over $18 \%$ af de afgivne stemmer pludselig en magtfaktor $i$ tysk politik. Det blev for alvor klart ved de følgende valg. Ved rigsdagsvalget i juli 1932 blev stemmeandelen fordoblet og kom op på 37,3\%. Trods et dyk ved valget i november samme år til 33,1\% blev Hitler den 30 . januar 1933 udnævnt til rigskansler. Hermed var vejen banet for den endelige magterobring.

Provinsen Slesvig-Holsten var en af NSDAP's højborge. I 1928 havde partiet kun fået 4,1\% af stemmerne, men ved valget i 1930 kunne det indkassere 27\%. Ved rigsdagsvalget $\mathrm{i}$ juli 1932 var det over halvdelen af de gyldige stemmer $(51,1 \%)$, der tilfaldt NSDAP. Fire måneder senere var det knap 46\%, der satte deres kryds ved dette parti.

Nord for grænsen så det anderledes ud. Ved udgangen af 1932 havde begejstringsbølgen for NSDAP endnu ikke sat sig større synlige spor inden for det tyske mindretal. Tværtimod havde mindretalsledelsen bevidst søgt at holde sig fri af den indre splid i Tyskland. Det havde afspejlet sig i Nordschleswigsche Zeitung. Bladet havde aldrig lagt skjul på sine borgerlige sympatier, når det orienterede læserne om de rigstyske begivenheder, men det havde omhyggeligt undgået at tage stilling for eller imod nazismen. 
Denne linje blev søgt opretholdt efter Hitlers udnævnelse til rigskansler. Den nye regering og udskrivningen af nyvalg blev nok udførligt omtalt $i$ avisen, men i en refererende stil. Tilsvarende kom oppositionens synspunkter nu og da til orde. Det gjaldt specielt modstanden mod opløsningen af den preussiske landdag - og herunder den måde nazisterne forhindrede den socialdemokratiske minister Severin $i$ at tale i landdagen. Den drastiske stramning af den tyske valglov blev nok hilst velkommen, men det blev med beklagelse konstateret, at de nationale mindretal i Tyskland hermed i praksis var udelukket fra at stille op. ${ }^{1}$ Som helhed var avisen meget tilbageholdende i sin dækning af den politiske situation i Tyskland op til rigsdagsvalget.

Det var helt $\mathrm{i}$ tråd hermed, at Nordschleswigsche Zeitung den 21. februar 1933 i en stort opsat anonym artikel, der formodentlig var skrevet af pastor Schmidt, advarede mod at spå om valgets udfald. Det blev kun i kryptiske vendinger konstateret, at det tyske folk ville træffe en afgørelse, der ville blive bestemmende for Tysklands skæbne i lang tid. Det afgørende var viljen til enighed "... og den takt, som folket marcherer i ...«. Resten af artiklen var viet de nordslesvigske forhold, hvor det blev fremhævet, at det tyske mindretal siden 1920 havde realiseret den nationale enhed inden for egne rækker. Det var møntet herpå, at artiklen havde fået overskriften "selvbeherskelse og tillid «.

I provinsen Slesvig-Holsten var man dog ikke tilfreds med denne selvbeherskelse inden for det tyske mindretal. Det kom klart til udtryk, da NSDAPs sagkyndige i det slesvigske grænsespørgsmål, pastor Johann Peperkorn, den 24. februar 1933 indledte et oratorisk stormløb mod grænsen. Brodden blev her også vendt mod den hjemmetyske presse, der ifølge Peperkorn havde "svigtet jammerligt « med hensyn til omtalen af nationalsocialismen i Tyskland.

Tre dage senere blev talen gengivet på forsiden af Nordschleswigsche Zeitung. Det nævnte udfald blev kommenteret med en bemærkning om, at mindretallets presse i henhold til »en truffen beslutning “ ikke blandede sig i tysk indenrigspolitik. Dog glædede avisen sig over, at der under de nye forhold i Tyskland også blev tænkt på tyskerne i de afståede områder "... med ganske særlig kærlighed og omsorg, og at båndet mellem vort fædreland og os skal knyttes endnu fastere end hidtil«. ${ }^{2}$ Det blev det hurtigt. I de følgende uger steg presset - såvel udefra som indefra. Det blev starten på et kursskifte, som også fik politisk betydning for mindretallet. 
Rigdagsbranden den 27. februar blev for Nordschleswigsche Zeitung optakten til en mere intens - og ensidig - omtale af den politiske udvikling i Tyskland. Lige som den nazistiske presse var avisen ikke i tvivl om, at det var kommunisterne, der var de skyldige. Klapjagten mod dem og udstedelsen af de nye nødforordninger, der satte frihedsparagrafferne i Weimarforfatningen ud af kraft, blev udførligt omtalt og begrundet med truslen om et kommunistisk kupforsøg. Samtidig blev det antydet, at de tyske socialdemokrater havde haft en finger med i spillet ${ }^{3}$.

Efter denne optakt bekendtgjorde Nordschleswigsche Zeitung den 6. marts med stor begejstring, at nationalsocialisterne og de tysk-nationale havde fået 340 af rigsdagens 647 pladser ved valget den foregående dag og dermed absolut flertal. I en redaktionel kommentar skrev avisen, at det tyske folk hermed havde givet Hitlers regering et tillidsvotum og bemyndiget den til at fortsætte ad den vej, "... som den har begyndt så løfterigt. Tyskland står altså i de næste år ikke under et diktatur, derimod under en regering, som udtrykker folkeviljen «. Det var på denne baggrund, at det tyske mindretal ifølge avisen hilste valgresultatet velkommen "... med taknemmelig glæde og med ny styrket forhåbning til fremtiden«.

Med til at befæste dette indtryk var den højtidelighed, der fandt sted den 21. marts 1933 i garnisonskirken i Potsdam ved rigsdagens åbning. Den stort iscenesatte begivenhed, Hitlers radiotransmitterede tale og hans optræden sammen med Hindenburg gjorde et dybt indtryk. Det blev udførligt omtalt $\mathrm{i}$ avisen og under overskriften "gammel storhed og ny kraft « betegnet som en besegling af forbundet mellem rigskansleren og rigspræsidenten. Hermed fik det nye styre i konservative tyske øjne en legitimitet, der rakte ud over rigsdagsvalget. Et ydre udtryk herfor var også Hindenburgs bestemmelse om, at hagekorsflaget ved officielle lejligheder i fremtiden skulle hejses sammen med rigsflaget. ${ }^{4}$

Fra da af blev omtalen af Hitler og nazismen daglig kost i det tyske mindretals avis. Da kansleren en måned senere fyldte 44 år fik han en hyldest i Nordschleswigsche Zeitung, som langt overgik nogen af hans forgængere i Weimartiden. Foruden på det meste af forsiden blev Hitler hyldet på en hel side inde i bladet. Overskriften var her "Kämpfer! Führer! Mensch! Zum Geburtstag unseres Volkskanzlers« - garneret med naziflag, naziemblem, heilende hænder og mange billeder. ${ }^{5}$ 
omtalte - korruptionsskandaler. Konklusionen herpå var, at det kun var et spørgsmål om tid inden det tyske socialdemokrati blev opløst. Om den dybere årsag og virkning blev der ikke talt. Det var formodentlig tilfældigt, at artiklen blev offentliggjort på Hitlers fødselsdag. Men sammenlignet med de ovenfor omtalte hyldetsartikler til kansleren var det en klar demonstration af, hvor langt bladet havde flyttet sig på mindre end to måneder. ${ }^{6}$

Med et oplag i februar 1933 på 3.250 eksemplarer nord for grænsen, der ved en hvervekampagne i marts blev oget til 3.650, var Nordschleswigsche Zeitung den vigtigste enkeltkilde til information for det tyske mindretal ${ }^{7}$. Hertil kom danske og $i$ et beskedent omfang rigstyske aviser. Efter Hitlers udnævnelse til kansler fik tysk radio imidlertid også en øget betydning for den daglige nyhedsformidling. Tysksindede i Nordslesvig kunne her i bogstaveligste forstand time for time følge med i de store begivenheder - og blive påvirket af den nazistiske propaganda. Særlig virkning gjorde det uden tvivl, at Hitlers stemme nu i direkte transmissioner nåede ind i hver stue og kunne tryllebinde sine tilhørere. Det var inden for rammerne af dette mediebillede og styrket ved personlige kontakter over grænsen, at dele af det tyske mindretal begyndte at røre på sig i foråret 1933.

Indtrykket af udviklingen i Tyskland blev forstærket af reaktionerne i Slesvig-Holsten, hvor mindretallet på nært hold kunne forvisse sig om den nazistiske bevægelses kraft. Det gjaldt f.eks. de hjemmetyskere, der den 24. februar overværede pastor Peperkorns grænsepolitiske tale i Flensborg, og de 13 unge tysksindede nordslesvigere, som den følgende dag kom til byen for at deltage i et 8-dages Turnerfreizeit-kursus. Da de sidstnævnte vendte hjem, var de ifølge Reinhold Hesse »som forvandlede «.

Ved de kommunale valg i midten af marts var alt endnu roligt på overfladen. Valgkampen kørte i det gamle spor med prøvede kræfter. Mindretallet kunne notere en beskeden fremgang målt i stemmer, men procentuelt gik det tilbage i flere købstæder og flækker. Den 16. marts sammenfattede lederen af de tyske privatskoler i Nordslesvig, Wilhelm Koopmann, imidlertid stemningen $i$ et brev til formanden for Schleswig-Holsteiner Bund, Wilhelm Sievers. Han skrev, at mindretallet tydeligt kunne mærke, at situationen i Tyskland nu var helt anderledes end for ét år siden. Den nye udvikling virkede stærkt opmuntrende og gav håb for fremtiden. Ifølge Koopmann kunne der i 

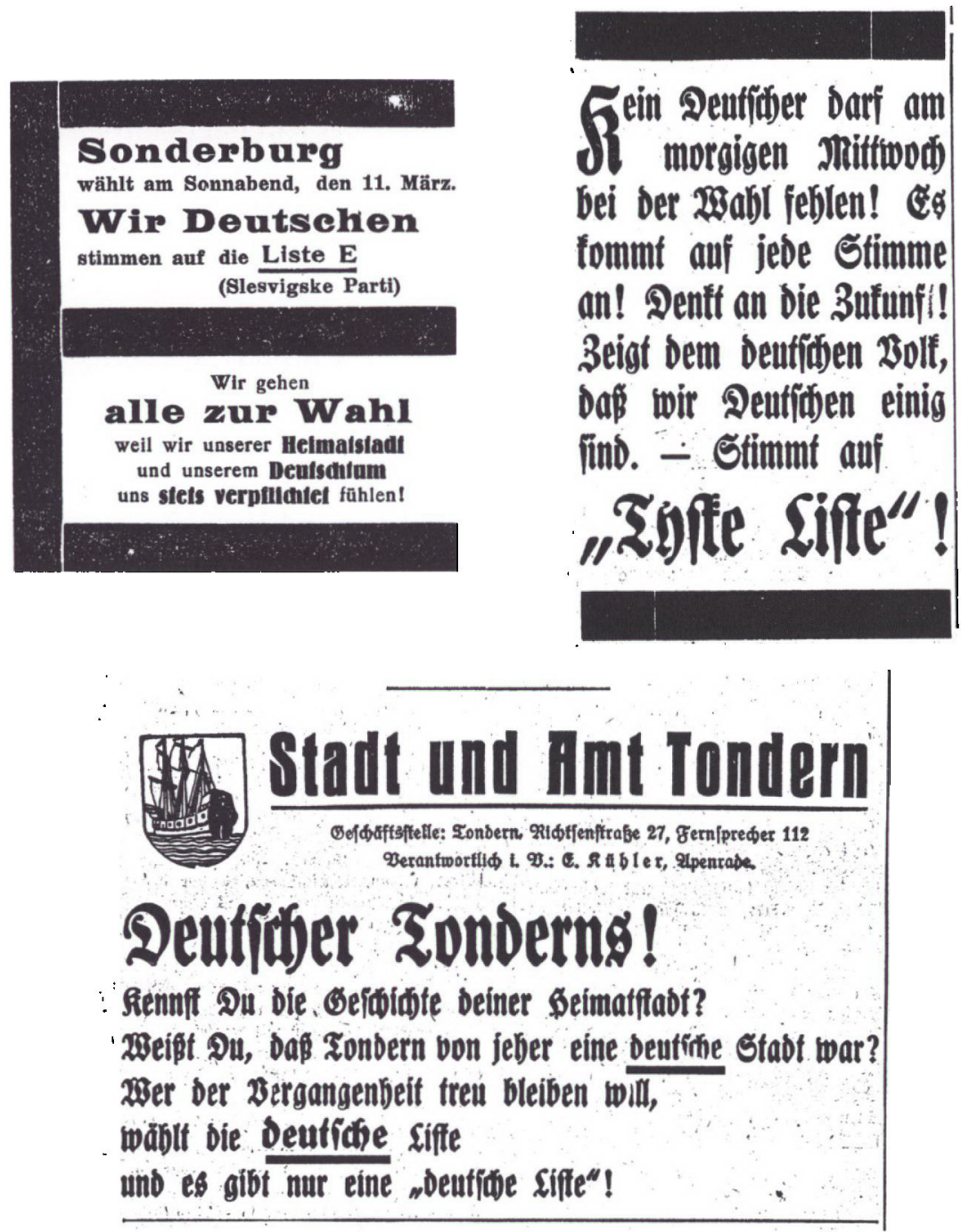

Med disse annoncer opfordrede Nordschleswigsche Zeitung hjemmetyskerne $i$ Tonder, Aabenraa og Sønderborg til at møde op og stemme på den tyske liste, Slesvigsk Parti, ved kommunevalget 7. og 11. marts 1933 .

hjemmetyske kredse igen spores en følelse af, at mindretallet ikke ville blive ladt i stikken af de tyske brødre. ${ }^{9}$

Sievers gjorde sit til, at mindretallet ikke blev glemt. I de samme dage gjorde han i en artikel, som blev gengivet i Nordschleswigsche 
Zeitung den 18. marts, nærmere rede for Schleswig-Holsteiner Bunds program. Han slog her til lyd for en grænserevision og gav tilsagn om åndelig og materiel støtte til det tyske mindretal. Det var efter dette forvarsel, at barometeret stod på storm, da han den 24. marts 1933 i Ekernførde proklamerede: "Vi vil have Nordslesvig tilbage!“ Det blev ledsaget af en kraftig appel til mindretallet og her især den hjemmetyske ungdom om at gå ind i kampen.

Temaet var det samme - men havde en mere håndfast form, da pastor Peperkorn den 5. april holdt en stor tale ved 84-årsdagen for træfningen ved Ekernførde. Efter at have erklæret, at nøden i Nordslesvig "... vil tvinge København til at gå til Berlin", udtalte han: "Den kærlighed, som mange oprigtige nordslesvigere i de første år efter genforeningen har næret til Danmark, er nu afløst af et infernalsk had til Danmark, og et håb om befrielse er tændt. Den dag vil derfor oprinde, da "gaden er åben og fri for de brune batailloner«. Det bliver dag for dag mere klart, at Tysklands skæbne også er Nordslesvigs«.

De nævnte tilkendegivelser førte til en indgriben fra Berlins side, der tvang de slesvig-holstenske nazister til at rebe sejl m.h.t. grænserevisionskravet. Men de var med deres taler med til at bryde det politiske dødvande inden for mindretallet og puste liv i nazismen nord for grænsen, hvilket uden tvivl også var det vigtigste formål med hele aktionen.

\section{Første tysk-nazistiske manifestationer}

Den 22. marts 1933 indeholdt Nordschleswigsche Zeitung en hagekors-smykket annonce, hvor det blev bekendtgjort, at der den følgende dag ville blive afholdt en »tysk aften « $\mathrm{i}$ Tønder, hvor lærer Lutz fra Süderlügum ville tale om emnet: "Ein neues Deutschland ist erwacht «. Mødet var, som avisen senere refererede, arrangeret af lokale nazister med hjælp af venner sydfra. Da aftenen oprandt var Deutsches Haus fuldt besat med tilhørere. Blandt dem var der også medlemmer af S. A. og Hitlerjugend fra Süderlügum. Det var således helt korrekt, da Lecker Anzeiger sluttede et referat af mødet med at skrive, at "... spidsen af de brune batailloner har dermed betrådt Tønder og Nordslesvig «. Salen var pyntet med hagekorsbannere og tyske flag; på scenen var der anbragt et transparent med ordene: "Nordschleswig, erwache!« 


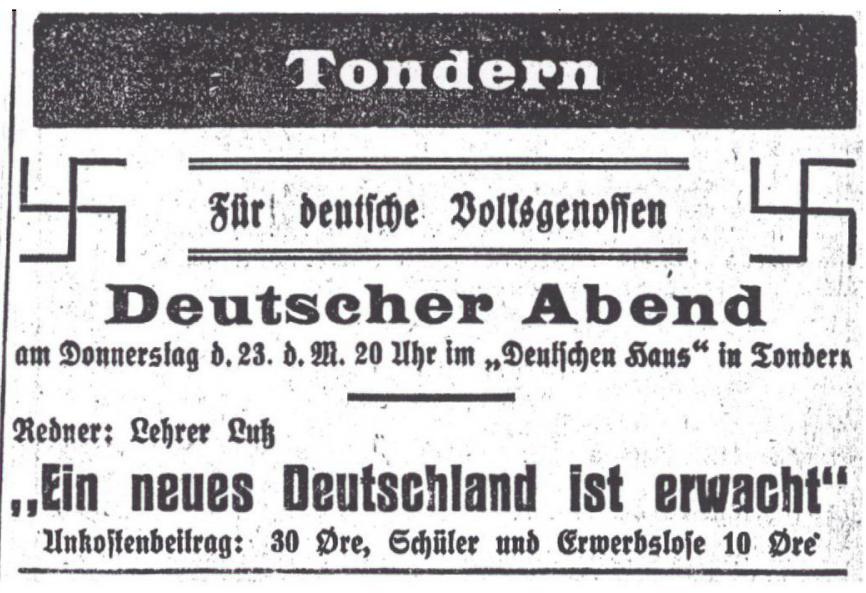

Denne annonce $i$ Nordschleswigsche Zeitung fra 22. marts 1933 er et af de forste signaler om den fremvoksende nazificering af mindretallet.

Efter sang og talekor holdt lærer Lutz en flammende tale. Han indledte med at udtale, at det næsten var beskæmmende for tyske nationalsocialister at træde frem for tysksindede nordslesvigere, der havde bevaret deres tyskhed meget bedre end tyskerne i riget. Efter således at have sikret sig lydhørhed, omtalte han det tyske riges forfald $i$ tiden efter 1871 og kritiserede specielt de tyske socialdemokrater for under påvirkning af jøder at have svigtet. Men takket være Hitler var man nu ved at skabe et stort tysk folkefællesskab. Nationalsocialisterne var ifølge Lutz rede til at kæmpe med deres blod for det nye Tyskland og træde i skranken for udenlands-tyskerne "... for at de to millioner faldnes stumme anklage ikke omsonst skal blive sand «. Taleren blev ifølge Nordschleswigsche Zeitung flere gange afbrudt af begejstrede tilråb, men det var tydeligt, at det voldte referenten nogen vanskelighed at følge med $\mathrm{i}$ det nazistiske tankegods.

Efter afsyngelse af Horst-Wessel-sangen optrådte Hitlerjugend med sang, digte og en fanerunddans. Herpå var der igen taler. Lærer Martensen gav bl.a. en skildring af Hitlers levnedsløb og den nationalsocialistiske bevægelses udvikling, mens lærer J. Hansen, Saksborg, luftede sin begejstring for nazismen. Midt i det hele blev der også sendt et telegram til Hitler. Da aftenen sluttede havde 27 mænd skrevet under på, at de var rede til at kæmpe for det nye Tyskland. Mødet i Tønder blev hermed ikke kun den første tyske nazistiske manifesta- 
tion i Nordslesvig, men også det første skridt til en ny hjemmetysk partidannelse. ${ }^{10}$

Det blev starten på en bølge af begejstring, der i de følgende uger rullede gennem mindretallet. Det kom bl.a. til udtryk, da Haderslebener Turnerbund den 26. marts havde gymnastikopvisning. Ved festen om aftenen kom formanden, Kaadtmann, ind på de store begivenheder i Tyskland. I den forbindelse nævnte han, at Turnerbunds rigstyske hovedorganisation, Deutscher Turnerschaft, havde opfordret alle medlemsforeningerne til at slutte op om den nationale rejsning i Tyskland. Nok mindede Kaadtmann sine tilhørere om, at det tyske mindretal undgik at blande sig i enhver form for partipolitik i Tyskland, men han tilføjede, at Turnerbund ikke kunne forblive uberørt af denne opfordring. ${ }^{11}$ At det var tilfæeldet blev klart demonstreret, da Turnverband Nordschleswig 14 dage senere i en officiel erklæring uden forbehold bekendte sig til nationalsocialismen i Tyskland.

Inden da var der andre tilkendegivelser i samme retning. Ved flere møder blev udviklingen syd for grænsen hilst velkommen, lige som Horst-Wessel-sangen nu "selbstverständlich", som Nordschleswigsche Zeitung skrev, blev afsunget ved forskellige lejligheder. ${ }^{12} \mathrm{Et}$ fælles træk var det, som landsretssagfører Lauritz Clausen udtalte på et møde i Haderslev, at de tysksindede nok »med brændende hjerte« havde fulgt med $i$ begivenhederne $i$ Tyskland, men at de kun havde en uklar forestilling om nazismens væsen og mål. Nysgerrigheden og behovet for viden om den nye bevægelse var derfor stor. Tilsvarende måtte Nordschleswigsche Zeitung efter opfordring trykke teksten til nazistiske slagsange og bl.a. forklare sine læsere, hvilken forskel der var på SA og SS. ${ }^{13}$

Virkningen heraf kunne også aflæses i danske kredse. I begyndelsen af april 1933 kommenterede lærer Alfred Torp udviklingen i et brev til professor Aage Friis. Han skrev bl.a.: "... Nu vækkes med fagre ord erindringen om den "gode tyske tid ", og det går som en stille hvisken fra hus til hus i Tønders små sidegader, hvor de "alteingesessene " småborgere har til huse: "Vi bliver tyske igen - vi kommer igen ind i det store folk med de rige muligheder". Man oplever, at sådanne folk $\mathrm{i}$ fuld alvor siger til deres danske husfæller: »Nu bliver Tønder snart tysk, men så skal vi nok behandle jer godt, for danskerne har været gode mod os siden genforeningen «. ${ }^{14}$

I Sønderborg var der - for at blive i Torps sprogbrug - ikke tale om en stille hvisken. Den 7. april klagede folketingsmand I. P. Nielsen 
i den lokale avis over, at det tyske mindretal var blevet fuldstændig »opfanatiserede«. Unge mennesker drog gennem byens gader med heilråb; hagekorsmærker, flag og plakater blev demonstreret åbenlyst, og på restaurant kunne man høre gæster synge "Ich bin ein Preusse ${ }^{15}$

\section{Wählerverein og de kritiske}

En del tysksindede forholdt sig dog passive - eller kritiske - over for den nye bevægelse. Det gjaldt ikke kun tysksindede socialdemokrater, men også borgerligt indstillede. Det var med henblik på den sidstnævnte gruppe, at Nicolaus Schmidt, Tønder, i Nordschleswigsche Zeitung søgte at bortvejre sine landsmænds skepsis mod nazismen. Han beklagede således, at mange »ulastelige" tysksindede i Nordslesvig, som ikke ville have det mindste at gøre med marxismen, stod skeptisk, »ja fremmed ", over for nationalsocialismen. Han begrundede det med, at de måske læste for mange danske aviser, og at de måske også var for konservative til at kunne løsrive sig fra parlamentarismen. Det sidste var der imidlertid råd for. Ifølge Nicolaus Schmidt drejede det sig nemlig ikke om at skifte parti, men om et systemskifte - "altså en revolution «. En af fordelene herved var, at man undgik den klassekamp, som Schmidt mente var en følge af det parlamentariske system, og ulempen ved, som han skrev med et Bismarck citat, at $» .$. hvor flertallet afgør, der sejrer dumheden ${ }^{16}$

De omtalte betænkeligheder i de tyske rækker kom dog ikke offentligt til udtryk på anden måde. Tværtimod var det begejstringen og den nye aktivisme, der prægede udviklingen.

Mest markant var det manifest, som over 100 repræsentanter fra forskellige tyske ungdomsforeninger vedtog den 9. april 1933 på Knivsbjerg. De bekendte sig her offentligt til »den nationale rejsnings gennembrud i Tyskland « og lovede at arbejde med på den nationale og socialistiske opbygning af det nye rige i Nordslesvig. Det ville de bl.a. gøre ved at stille sig som "marchkolonne" bag de paroler som blev udstukket af deres politiske ledelse.

At det også ville få konsekvenser for andre dele af mindretallet fremgik af to særskilte resolutioner, der ikke blev offentliggiort, men tilstillet Schleswigscher Wählerverein. I den ene blev der stillet krav om, at Nordschleswigsche Zeitung skulle omdannes til et slagkraftigt kampmiddel; under efterfølgende forhandlinger fremgik det, at det 
var bladets redaktør, Julius Kähler, som den hjemmetyske ungdom ønskede fjernet. I den anden var det Wählerverein selv, der var bud efter. I en resolution blev det således kort og godt slået fast, at Wählervereins opbygning og personkreds ikke levede op til den nye tids krav. Den politiske organisation skulle i stedet omdannes til et "kampfællesskab«, som også omfattede den yngre generation.

Det var repræsentanter fra de tyske ungdomsforeninger, gymnastikforeninger, roklubber, spejderforeninger, Verbindung schleswigscher Studenten og Hitlerjugend, der stod bag de nævnte tilkendegivelser. Den sidstnævnte rigstyske organisation var ifølge en meddelelse i Schleswig-Holsteinische Tageszeitung representeret ved tre afdelinger i Haderslev, Tønder og Aabenraa. Af resolutionerne fremgik det, at der var blevet dannet et aktionsudvalg, som gennem forhandling skulle sikre kravenes gennemførelse. En af de drivende kræfter var lærer Hans Martin Johannsen, Sønderborg. ${ }^{17}$

Efter denne bekendelse til nazismen og det 3. rige var det den ældre generations tur til at tage ordet. Det skete den 10. april 1933, da Schleswigscher Wählerverein på et stort møde i Tinglev med $\mathrm{o}$. 350 deltagere tog stilling til den seneste tids begivenheder. Pastor Schmidt slog tonen an ved at udtrykke sin glæde over det nye Tyskland og den entusiasme, det havde fremkaldt hos ungdommen både indenfor og udenfor riget. Samtidig betonede han imidlertid, at Tyskland og udenlandstyskerne ikke var ét og det samme, da de levede i forskellige stater med hver sit særlige ansvar. Det som nationalsocialismen først og fremmest kunne forvente af det tyske mindretal var, at det som kender af hjemstavnen og nabofolket tjente det nye Tyskland med sine erfaringer. Der blev hermed signaleret en klar arbejdsdeling mellem mindretal og moderland.

Samtidig opfordrede Schmidt den hjemmetyske ungdom til at engagere sig stærkt i Wählerverein. Det skete med en bemærkning om, at det naturmæssigt nok var ungdommen, der trængte mest stormende frem, men at den også burde besidde så megen sindighed, at den klogt tog bestik af de politiske begivenheder. Sammenfattende udtalte Schmidt, at "... vi har vores tyske linje, som vi følger, men vi ved også, hvad fælles hjemstavn betyder, og hvad det forpligtiger til.«

Det var disse to budskaber, der gik igen i den afsluttende resolution, som blev vedtaget af forsamlingen. Hovedparten heraf var dog blevet offentliggiort af pastor Schmidt to dage tidligere i en udtalelse til Nordschleswigsche Zeitung. I resolutionen blev det udtalt, at Wäh- 


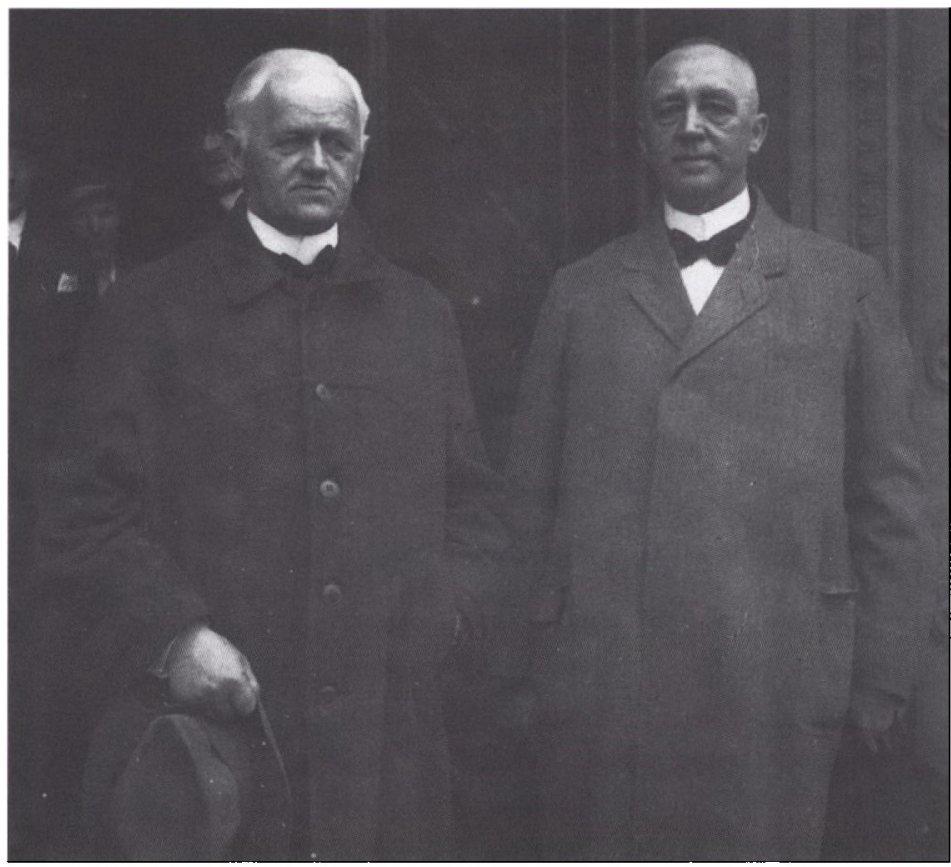

Pastor Johannes Schmidt fotograferet den 7. maj 1932 sammen med bankdirektor J. Erichsen fra Kiel. Foto: Institut for Sønderjysk Lokalhistorie.

lerverein »som organ for det tyske Nordslesvigs politiske vilje« hilste det nationale gennembrud i Tyskland velkommen, som en fast vilje til at genoprette tysk ære og frihed. I tråd hermed gentog Wählerverein sit gamle krav om en grænserevision, men den skulle åbenbart nu omfatte hele Nordslesvig. Kernen i resolutionen var imidlertid en understregning af, at der hele tiden havde eksisteret en samlet tysk front i Nordslesvig. Besværgende blev det understreget, "... at en splittelse kender vi ikke. Den ville kun svække vor viljes slagkraft«. Wählerverein havde hermed nok taget handsken op, og støttet de slesvig-holstenske nazisters krav om en grænserevision, men samtidig markeret, at den ønskede at forblive herre i eget hus. ${ }^{18}$

Ifølge det offentliggjorte referat af mødet, var det som helhed en urokkelig bekendelse til Wählervereins og pastor Schmidts linje. Formanden blev da også æret med et dundrende »Hoch«. Det samme gjaldt imidlertid en anden person, som ikke deltog i mødet. Da forsamlingen sang "Hitlerlied ", som redaktør Kähler bagefter berettede, 
røg næsten alle hænder op til Hitler-hilsen. ${ }^{19}$ Det var et umiskendeligt tegn på, at det nye Tyskland også ville få politiske konsekvenser for mindretallet.

\section{Første spirer til et hjemmetysk naziparti}

Siden grundlæggelsen i 1920 havde Schleswigscher Wählerverein uantastet virket som den tysksindede befolknings politiske organisation. Ved de kommunale valg blev der brugt forskellige betegnelser - f.eks. Tysk Liste, men ved rigsdagsvalgene stillede mindretallet altid op under navnet Slesvigsk Parti. Pastor Schmidt havde i alle årene fungeret som mindretallets politiske leder og folketingsmand. Nogle gange var der blevet sat spørgsmålstegn ved hans politiske linje og løbet storm mod ham specielt af de såkaldte Kongeåfolk fra det urolige Haderslev. Men det var hver gang lykkedes ham at afparere stødene.

For pastor Schmidt var det et dogme, at mindretallet ikke skulle blande sig i rigstysk partipolitik, og omvendt - hvad der var nok så vigtigt - at de rigstyske partier ikke havde noget at komme efter $\mathrm{i}$ Nordslesvig. Dette standpunkt blev luftet ved mange lejligheder og som nævnt gentaget i Wählervereins resolution den 10. april 1933 i Tinglev.

I 1920'erne havde det ikke været noget problem. De tyske partier havde ikke noget incitament til at etablere sig uden for riget, og ingen af dem øvede nogen særlig tiltrækning på hjemmetyskerne. Nu og da havde repræsentanter fra f.eks. Stahlhelm eller Tannenbergbund vakt opsigt, men det havde kun været krusninger på overfladen. Tilsvarende havde NSDAP ikke sat sig spor nord for grænsen. Efter alt at dømme var det kun de færreste, der før partiets store sejr ved rigsdagsvalget $i$ september 1930 havde et nærmere kendskab til det. En af dem var Christian Bruhn, Aabenraa, der i 5 år frem til januar 1933 havde kørt med fiskebiler til Berlin, Rostock og Hamburg og dermed haft lejlighed til at følge udviklingen på nært hold. Det samme gjaldt Jef Blume fra Nørre Løgum, der fra 1927 til 1933 gik på Friedrich Paulsen Schule i Nibøl. Her lærte han nazismen at kende og var i 1930 med til at oprette en nationalsocialistisk elevforening ved skolen. I juni 1931 besøgte han sammen med ligesindede Tønder for at oprette en nationalsocialistisk elevgruppe på den danske side af grænsen, men det førte dog ikke til noget i første omgang. Da elevforeningen blev forbudt i Nibøl, blev Blume i stedet medlem af Hitlerjugend. ${ }^{20}$ 
Det var efter alt at dømme først i 1932, at NSDAP's eksplosive fremgang - der var særlig markant i provinsen Slesvig-Holsten skærpede interessen hos nogle af de tysksindede nordslesvigere. Resultatet var, at flere nu i smug søgte et nyt politisk ståsted. Det skete dels ved tilslutning til surrogatet Danmarks Nationalsocialistiske Arbejder Parti - DNSAP, dels ved at særligt ivrige tog over grænsen og opsøgte den ægte vare i NSDAP's skikkelse.

Blandt de danske nationalsocialistiske smågrupper og partier, der opstod i begyndelsen af 1930'erne i kølvandet på Hitlers valgsejre, var det Danmarks Nationalsocialistiske Arbejder Parti, der fik størst berøring med det tyske mindretal. Partiet blev stiftet den 16 . november 1930 af ritmester Cai Lembcke. I januar det følgende år dukkede det op syd for Kongeåen, da Lembcke afholdt et møde i Sønderborg. Her mødte han dyrlæge Frits Clausen, Bovrup, der efter at have sluttet sig til partiet blev sønderjysk distriktsleder og redaktør af ugebladet »National-Socialisten«. Det var i denne egenskab, at Frits Clausen den 29. maj 1932 bød velkommen ved DNSAP's første møde i Aabenraa på Hotel Royal, og det var også i denne by, at partiets hovedkvarter blev placeret, indtil det nogle år senere flyttede til Bovrup. I sommeren 1932 lykkedes det en kort overgang for Lembcke at samle næsten alle nazistiske fraktioner under sit førerskab, men det følgende år blev han væltet og efterfulgt af Frits Clausen. ${ }^{21}$

Indtil foråret 1933 var DNSAP den eneste organisation i Nordslesvig, der repræsenterede de nationalsocialistiske ideer. Herved kom det til at øve en vis tiltrækningskraft på flere hjemmetyskere. I begyndelsen af juli 1932 gjorde Wählervereins Ortsgruppe i Højer hovedbestyrelsens næstformand, H. B. Jepsen, opmærksom på, at en række tysksindede borgere og bønder havde meldt sig ind $\mathrm{i}$ det danske nazistparti. Det kom ikke helt bag på H. B. Jepsen, der i mangel af den ægte vare selv var blevet medlem af DNSAP. Da det blev offentligt kendt, blev han kort tid efter presset til at nedlægge sit hverv som næstformand og udtræde af Wählervereins hovedbestyrelse. Inden da havde $\mathrm{H}$. B. Jepsen imidlertid taget til genmæle. Han begrundede sin indtræden i partiet med, at han længe havde sympatiseret med nationalsocialismen i Tyskland. Efter at han havde erfaret, at mange såvel unge som ældre hjemmetyskere havde sluttet sig til den danske udgave af bevægelsen, havde han følt sig forpligtet til at gå med, for at påvirke den i den rigtige retning. Det var i tråd hermed, at Georg Vogelgesang i oktober samme år kunne 
berette, at mange unge tysksindede frlte sig draget af den danske nazisme. ${ }^{22}$

Ved folketingsvalget i november 1932 havde de danske nazister ikke formået at samle de fornødne 10.000 underskrifter til at stille op i hele landet. På grund af de særlige sønderjyske valgregler kunne de imidlertid tage del i valget her. Det gav dog kun 757 stemmer på DNSAP svarende til ca. $1 \%$ af de i landsdelen afgivne stemmer. ${ }^{23}$ Valget var også en skuffelse for Slesvigsk Parti. Nogle uger senere gjorde lederen af den tyske skoleforening $i$ et brev til dr. Edert rede for tilbagegangen i de to grænsesogne Bylderup og Bov. Koopmann skrev, at L. S.-bevægelsen og Socialdemokratiet havde gjort indhug i de tyske rækker. Tilsvarende mente han, at de stemmer som DNSAP havde fået $\mathrm{i}$ de to sogne, »overvejende « var blevet afgivet af tysksindede vælgere. Tilsvarende skrev den tyske konsul i en indberetning til Auswärtiges Amt om det samlede valgresultat, at "... man formoder også, at stemmer fra unge hjemmetyskere i flere tilfælde er blevet afgivet på de danske nationalsocialister «. ${ }^{24}$

Det er imidlertid påfaldende, at DNSAP fik meget lave stemmetal i de fleste tyske »højborge«. Det gjaldt bl.a. de fire købstæder, hvor Aabenraa toppede med 38 stemmer. I Haderslev, Sønderborg og Tønder var det henholdsvis 19, 10 og 14. I Tinglev og Højer var tallene endnu lavere. Det samme gælder de ovenfor nævnte grænsesogne Bov og Bylderup samt Ubjerg. På Frits Clausens hjemmebane i Bovrup var det kun gået en smule bedre med 19 stemmer. De sogne, hvor DNSAP havde klaret sig bedst, var i nævnte rækkefølge Vedsted, Toftlund, Øster Løgum, Varnæs og Felsted, der i tilslutning svingede mellem 64 og 40 stemmer. De fleste af dem lå uden for Slesvigsk Partis kerneområde - den såkaldte »skæve firkant«. Mere bemærkelsesværdigt er det, at Slesvigsk Parti sammenlignet med det foregående folketingsvalg var gået markant frem i fire af de fem sogne og i Øster Løgum sogn kun havde mistet fire stemmer. Og det ved et folketingsvalg hvor Slesvigsk Parti måtte notere en generel tilbagegang i hele Nordslesvig fra $14,3 \%$ til $13,3 \%$ af de afgivne stemmer. ${ }^{25}$ Det var således efter alt at dømme begrænset, hvor mange tysksindede der havde stemt på DNSAP.

Nordschleswigsche Zeitung havde i juli 1932 stærkt advaret de tysksindede mod at melde sig ind i det danske nazistparti. Helt så kategorisk var avisen ikke, når det gjaldt NSDAP i Tyskland. Her blev der gjort en dyd af nødvendigheden og udtrykt en vis beklagende 


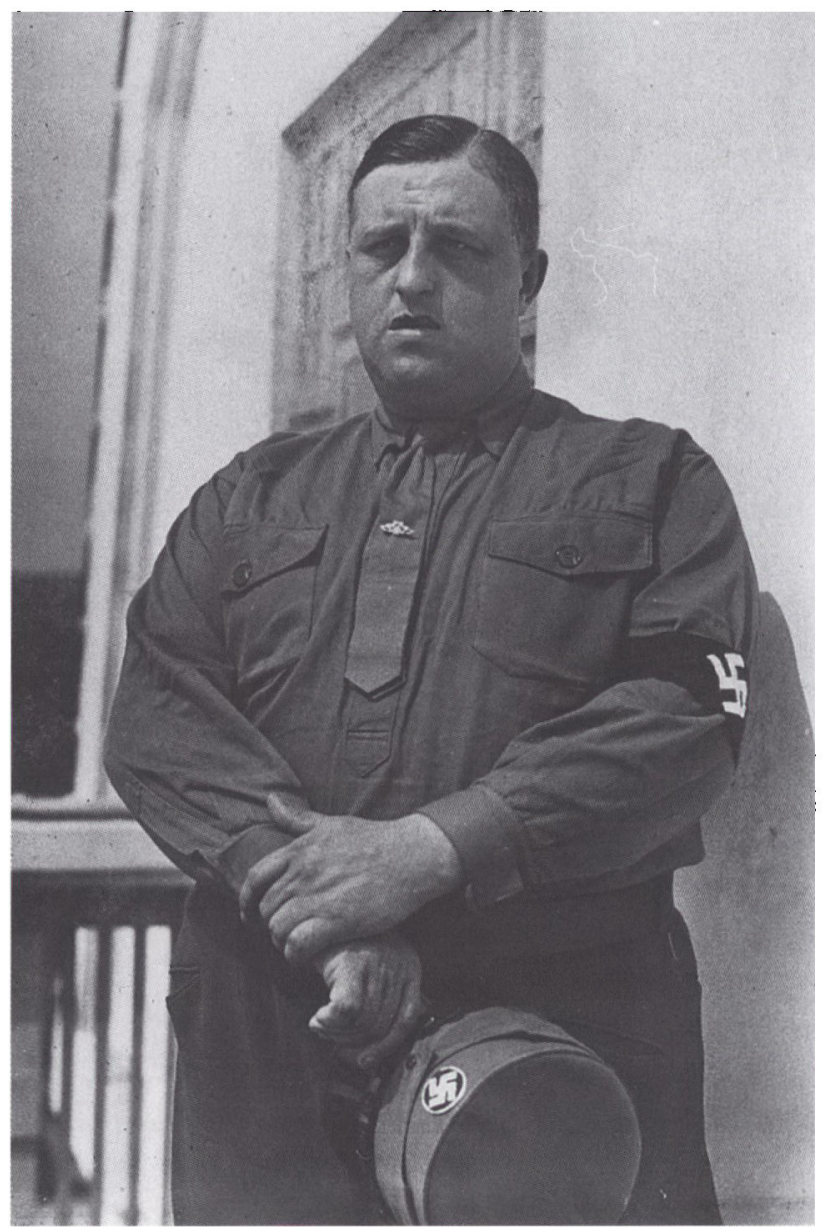

Den danske nazi-

leder Frits Clausen i forerpositur.

Foto: Institut for Sønderjysk

Lokalhistorie.

forståelse for, at nordslesvigere kunne føle sig tiltrukket heraf. ${ }^{26}$ Det gjaldt bl.a. en lille gruppe tysksindede $\mathrm{i}$ Tønder på syv personer, der i sommeren 1932 tog til Süderlügum for at blive indmeldt i partiet og herpå regelmæssigt deltog $\mathrm{i}$ de lokale møder. Gruppen skulle samtidig arbejde som »venner « af NSDAP i Tønder. For at forstærke indsatsen kom Udo Michelsen, Süderlügum, i november jævnligt til byen for at hverve medlemmer til Hitlerjugend og grundlægge en "Standort«. Selv om flere meldte sig ind, blev der dog ikke gjort tjeneste $i$ tiden før Hitlers magtovertagelse. ${ }^{27}$ I Aabenraa blev der i 1932 også dannet en lille nazigruppe med bibliotekar Frederik Christensen som 
»Schulungsleiter «. En af deltagerne, før omtalte Christian Bruhn, betegnede den senere som den første blok i byen - et udtryk der var hentet fra den nazistiske parti-terminologi. ${ }^{28}$

Det må formodes, at der opstod tilsvarende studie-grupper andre steder i landsdelen. I hvert fald kunne Ernst Schröder i august 1932 efter et møde med Gauleiter Hinrich Lohse, SA-fører Meyer-Quade og de lokale naziledere i Flensborg berette, at 0.300 nordslesvigere havde meldt sig ind i NSDAP. Lohse havde ved den lejlighed beklaget sig over, at tysksindede nordslesvigere følte sig tiltrukket af det danske nazistparti og nævnt muligheden af, at NSDAP selv ville oprette egne afdelinger nord for grænsen. Det var imidlertid blevet stærkt frarådet af Schröder, der bl.a. havde argumenteret med, at det ville få den tyske enhedsfront i Nordslesvig til at bryde sammen og true mindretallets repræsentation i Folketinget. Efter nye drøftelser blev planerne åbenbart skrinlagt i denne omgang.

Det var på den baggrund, at det tyske gesandtskab i København i november 1932 umiddelbart før folketingsvalget kunne glæde sig over, at nazisterne inden for mindretallet ikke "... har opstillet en egen kandidat, men vil støtte Wählervereins kandidater ${ }^{29}{ }^{29}$ Et forsøg i begyndelsen af januar 1933 i Tønder på at oprette en ortsgruppe blev heller ikke til noget. Det blev senere af de pågældende begrundet med, at Nordschleswigsche Zeitung havde nægtet at indrykke en bekendtgørelse om afholdelsen af en hverveaften, men det er muligt, at det var manglende opbakning sydfra, der gjorde udslaget. ${ }^{30}$

Hitlers udnævnelse til rigskansler den 30 . januar 1933 betød ikke nogen øjeblikkelig ændring af den hidtidige linje. De hjemmetyske nazister og deres sympatisører holdt fortsat en lav profil. Det var først $i$ begyndelsen af marts, at tavsheden blev brudt, da et par af dem lærer J. Hansen, Saksborg, og gårdejer Jep Nissen, Jyndevad - i to artikler i Nordschleswigsche Zeitung tog afstand fra, at folk fra mindretallet meldte sig ind i det danske nazistparti. For lærer Hansen var der, som han skrev, tale om en bodsgang, da han selv havde været medlem af partiet. I slutningen af måneden fik de svar på tiltale af en anden tysksindet. Det var mekaniker J. M. Jensen, Aabenraa, der forsvarede hjemmetyskernes tilslutning til DNSAP. Samtidig blev Jacob Hansen og Jep Nissen belært om, at de ikke havde erkendt nazismens væsen. Det affødte et gensvar fra de to herrer, men inden da var de selv med til at sætte en ny udvikling i gang inden for mindretallet. $^{31}$ 
Den »tyske aften« i Tønder den 23. marts 1933 blev som tidligere nævnt starten på en begejstringsbølge, der rullede gennem mindretallet. $\mathrm{Da}$ aftenen sluttede, havde 27 skrevet under på, at de var rede til at kæmpe for det nye Tyskland. Det var det første offentlige skridt $i$ Nordslesvig i retning af en hjemmetysk nazistisk partidannelse. Men i betragtning af at Deutsches Haus ifølge Nordschleswigsche Zeitung var fuld af mennesker og begejstringen stor, var det et beskedent resultat - især da nogle af de tilstedevarende i forvejen var medlemmer af NSDAP. Wilhelm Sievers' bombastiske tale den følgende dag i Ekernførde med krav om en grænserevision og opfordring til den hjemmetyske ungdom om at gå ind i kampen blev imidlertid signal til opbrud.

Den 28. marts offentliggjorde Nordschleswigsche Zeitung og Schleswig-Holsteinische Landeszeitung et enslydende opråb, der var forfattet af lærer Jacob Hansen, Saksborg. Under overskriften "Gaden er fri. Er vi beredte til opbrud? " skrev han lige ud, at mindretallet først på et sent tidspunkt havde beskæftiget sig nærmere med de indenrigspolitiske forhold i Tyskland. Mange havde været bange for, at Hitler ikke ville stå sin prøve som statsmand. Denne hjemmetyske afventen havde ifølge lærer Hansen været berettiget. Men nu hvor det havde vist sig, at Hitler ragede op over dem alle, skulle man skride til handling og betingelsesløst slutte sig til den nationale tyske revolution, for at den stormberedte ungdom ikke førerløst søgte tilslutning hertil ad omveje. Det sidstnævnte var en hentydning til det danske nazistparti. Opråbet sluttede med en opfordring til, at "... de, som med mig erkender situationen, dem beder jeg om samtykkende tilkendegivelse; det haster . $^{32}$

For at sætte handling bag ordene indkaldte lærer Hansens svigersøn, Jep Nissen, allerede den følgende dag til et møde på Saksborg Kro, hvor man den 1. april skulle diskutere »den tyske rejsning og os «. ${ }^{33} \mathrm{Da}$ dagen oprandt var det lærer Hansen, der selv var hovedtaler. Begejstret gjorde han rede for NSDAP's grundlag og mål i Tyskland. Efter at have talt mod marxisme, jødedom og pacifisme betroede han forsamlingen, at han siden han blev politisk myndig, altid havde været nationalsocialist, men "... uden at vide det “. Sådan mente lærer Hansen, at mange andre også havde det. Konsekvensen heraf var, at "... vi vil være et tysk nationalsocialistisk arbejderparti i Nordslesvig under ledelse af de fra Tyskland kommende ideer. Vi vil tilslutte og underordne os under tysk ledelse.« Man skulle først samle 
de tysksindede, der bekendte sig til det 3. rige, og herpå afvente befalinger om den organisatoriske opbygning.

Til det formål cirkulerede der en liste rundt i forsamlingen om dannelsen af et »arbejdsfællesskab«. Da aftenen sluttede, havde 65 personer indtegnet sig. Inden da havde en afdeling af Hitlerjugend i Tønder underholdt. På et spørgsmål fra lærer Hansen bekræftede forsamlingen et onske om, at Nordschleswigsche Zeitung skulle bringe nationalsocialistiske beretninger og artikler. Herpå takkede både H. B. Jepsen, Tinglev, og Jep Nissen de tilstedeværende for fremmødet. ${ }^{34}$ Det var dette møde i Saksborg - og ikke det før omtalte i Tønder - initiativtagerne senere opfattede som grundlæggelsen af det første hjemmetyske nazistparti.

Den 5. april blev den nye politiske aktivisme lyst i kuld og køn af de slesvig-holstenske nazisters sagkyndige i grænsespørgsmål. Ved Schleswig-Holsteiner Bunds mindefest i Ekernførde nævnte pastor Peperkorn, at han havde modtaget mange breve fra Nordslesvig med bøn om hjælp. »Efter moden overvejelse«, udtalte Peperkorn, »og indhentede informationer i Berlin vil vi efterkomme dette ønske. For kort tid siden er allerede de første tre tyske nationalsocialistiske organisationer oprettet i Nordslesvig, og nu vil vi sætte ind af al vor magt. Som et lyn vil den tyske nationalsocialisme tage Nordslesvig $i$ besiddelse. Ti, tyve, tredive, fyrre, halvtreds, tres, halvfjerds, ja firs organisationer vil blive oprettet udover Nordslesvig". Taleren var vidende om, at adskillige hjemmetyskere "af fortvivlelse havde sluttet sig til det danske nazistparti. Men han var bemyndiget til at erklære, at de inden den 15. april skulle være udtrådt af partiet, hvis de nogensinde ville gøre sig håb om at blive medlem af »... vore tyske nationalsocialistiske organisationer i Nordslesvig, hvis oprettelse vi nu går i gang med «. Det blev understreget med et udsagn om, at NSDAP nok bekæmpede den internationale marxisme, men at en tysk socialdemokrat stod de tyske nazister "hundrede tusind " gange nærmere end en dansk nationalsocialist. ${ }^{35}$

Med denne offentlige tilkendegivelse syd for grænsen var bolden givet op til en nazificering af det tyske mindretal. Det er i denne sammenhæng, man skal se de hjemmetyske ungdomsorganisationers resolutioner den 9. april 1933, hvor de gav tilsagn om, at de i Nordslesvig ville arbejde med på den nationale og socialistiske opbygning af det nye rige og krævede, at Wählerverein skulle omdannes til et nationalsocialistisk kampfællesskab. Det blev dog ikke pastor 
Schmidt og den eksisterende politiske ramme i form af Wählerverein, der kom til at føre an i denne udvikling.

\section{Pastor Schmidt i defensiven}

Da Hitler kom til magten i januar 1933 var pastor Johannes Schmidt 63 år gammel. Gennem alle årene tilbage til studentertiden i Greifswald havde han været en konservativ nationalist. Nok var han i tiden før 1918 gået ind for en mildere kurs over for den dansksindede befolkning end f.eks. Den tyske Forening, men han havde hele tiden været tilhænger af et Stortyskland inklusive Nordslesvig. Efter afståelsen af denne landsdel i 1920 blev det vigtigste mål for hans virke da også at vinde det tabte tilbage. I begyndelsen af 1920'erne satsede han på, at princippet om den nationale selvbestemmelsesret kunne vendes til tysk fordel og bruges som loftestang ved en kommende grænserevision; men da håbet om, at de tysksindede nogensinde ville blive i stand til at mønstre et flertal, svandt, satsede han i stedet på, at Danmark »frivilligt« ville afstå Nordslesvig til Tyskland. ${ }^{36}$

Det kan på denne baggrund ikke undre, at pastor Schmidt var modstander af parlamentarisk demokrati. Det fik han allerede lejlighed til at demonstrere i Weimarrepublikkens første leveår, hvor han i marts 1920 så med sympati på den tyske embedsmand Wolfgang Kapps konservativt inspirerede kupforsøg. Det var ud fra en opfattelse af, at der her endelig var en mand, som ville skabe "orden", og som ikke var bundet af partierne. I de følgende år gav han flere gange udtryk for sit mishag med de eksisterende demokratiske styreformer, der ifølge Schmidt kun fremkaldte kaos og indre splid. I stedet spillede begreber som "Führer" og "Gefolgschaft" en væsentlig rolle for Schmidt $i$ bestræbelserne på at samle det tyske folk. Det var i denne sammenhæng, at han i slutningen af 1920'erne viste interesse for højreradikale bevægelser som Stahlhelm, NSDAP, Bund Oberland og bondebevægelsen i provinsen Slesvig-Holsten. ${ }^{37}$ Man kunne derfor tro, at pastor Schmidt ville have haft let ved at tilpasse sig de nye tider. Det var imidlertid ikke tilfældet. Nok var han ikke demokrat, men han var heller ikke nazist. Trods det ideologiske slægtskab blev nazismens gennembrud i Tyskland den største politiske udfordring, som han kom til at stå over for i sine knap 13 år som leder af det tyske mindretal.

I Schmidts politiske univers var nazismen i tiden før 1933 en blandt 
flere brikker, som kunne bruges til at skabe den stat, som han anså for den rette. Ud fra sin konservative grundholdning så han med sympati på nationalsocialismen som en samlende og disciplinerende kraft, men han var kritisk over for flere af partiets standpunkter og bevægelsens radikale udslag. Det var set i dette lys, at Schmidt i 1930 frimodigt advarede Goebbels mod at lave skandale under et påtænkt besøg i København. Tilsvarende tog Schmidt i 1931 afstand fra flere af NSDAP's mærkesager. Samme år havde han også over for en bekendt advaret mod at gøre Hitler til en gud og opfordret til et bredere samarbejde med andre kræfter i det tyske samfund. ${ }^{38}$

I takt med NSDAP's stærke vækst forstummede den offentlige kritik. Men den blev atter luftet den 7. marts 1933, da Schmidt i et brev til dr. Ewoldt i Kiel ironisk skrev, at »... siden den 5 . marts har vi den nye regering, der selv kalder sig for "den nationale regering"." Schmidt mente i den forbindelse, at det var "... en absolut fejltagelse, hvis nationalsocialismen tror, at den har opnået den nationale samling ved at den forener over $40 \%$ af stemmerne i sig. Den store øvrige del af vores folk må man ikke drive over i en lidenskabelig opposition. Det er opgaven at påvirke denne blok og at stille folket over partiet«. På trods af det tyske socialdemokratis »mange synder«, skulle man ifølge Schmidt ikke underkende, at fagforeningerne havde været $i$ en sund udvikling i retning mod at opfatte sig som en del af det tyske folk og den tyske stat. ${ }^{39}$

Uanset al reverens over for det nye styre - og forsøg på at danse efter de nye takter - kneb det $i$ starten for ham ikke at lade en distancerende holdning skinne igennem. Det kom bl.a. til udtryk i efteråret 1933, hvor han skrev i den nye udgave af Volkskalender, at den tyske nazisme nok var bærer af positivt fornyende tanker og foryngende kræfter, men tilføjede at "... dens hele handlekraft og dens hele videre fremtid afhænger af, hvor vidt denne positive opbygning lykkes for den «. Det viste klart, at han endnu så på nationalsocialismen "udefra«. Samtidig virkede det - bevidst eller ubevidst - som om han satte spørgsmålstegn ved tusindårsriget, hvilket næppe styrkede kreditten syd for grænsen. ${ }^{40}$

I den samme artikel skrev pastor Schmidt, at det tyske folk "gennem vor viljestærke kansler « blev opdraget til en ensartet politisk vilje. Schmidt mente imidlertid, at det nye Tyskland selv var klar over, at det kun kunne lykkes ved at såvel det enkelte menneske som de enkelte folkelemmer udviste en stor selvansvarlighed. Med udtrykket 
»folkelemmer« tænkte han uden tvivl på det tyske mindretal i Nordslesvig. Det var da også her ormen gnavede.

Pastor Schmidt havde hele tiden modsat sig dannelsen af nazistiske grupper blandt de tyske mindretal uden for Tyskland. "Det går ikke“, skrev han i februar 1931 til en bekendt, "fordi det ville sprænge tyskhedens enighed uden for riget. Jeg vil opdrage mine folk til, at de ser det stærke og sunde i nationalsocialismen og vil bedre opnå det, end hvis der her optrådte en gruppe mod hvilken andre grupper så ville træde $\mathbf{i}$ opposition. « ${ }^{41}$ Det var denne frygt parret med uvilje mod, at mindretallet skulle blive styret af kræfter syd for grænsen, der set med pastor Schmidts øjne var det største "aber dabei « ved nazismen. Det var i tråd hermed, at Reichszentrale für Heimatdienst i sommeren 1932 kunne berette, at mindretallets ledere bestræbte sig på at holde den indenrigspolitiske splittelse i Tyskland fjernt fra tyskheden i Nordslesvig. Det var også inspireret heraf, at repræsentanter fra Jugendverband i begyndelsen af juli 1932 offentliggjorde en erklæring, der ikke kun advarede mod indtræden i det danske nazistparti men også mod tilslutning til »det tyske nationalsozialistiske parti«, der kunne føre til »... uoverskuelige farer for en partipolitisk splittelse af vores folkegruppe«.

Da Hitler kom til magten syv måneder senere tog Jugendverband nyt bestik, men Schmidt ændrede ikke kurs på dette punkt. Det kom bl.a. til udtryk, da han i midten af marts $1933 \mathrm{i}$ to store artikler priste det nye styre, men tilføjede at de tysksindede i Nordslesvig også fremover måtte udføre deres arbejde "under eget ansvar «. ${ }^{42}$ Temaet var det samme, da Wählervereins hovedbestyrelse $i$ begyndelsen af april i en resolution krævede, at den tyske nazisme kun måtte springe over grænsen, hvis det skete "... i forbindelse med vores førere, der nyder almen tillid, [og] som ellers ikke kan bære ansvaret for ledelsen ${ }^{43}$ Det sidstnævnte var en tom trussel. Men få dage senere blev ønsket om at være herre $i$ eget hus endnu engang skåret ud $i$ pap. Det var på Wählervereins store møde den 10. april i Tinglev, hvor Schmidt udtalte, at Tyskland og udenlandstyskerne ikke var ét og det samme, da de levede i forskellige stater med hver sit særlige ansvar. For at ingen skulle være i tvivl tilføjede han, at "... vi har vores tyske linje ...«. Som tidligere nævnt var den afsluttende resolutions ord om, »... at en splittelse kender vi ikke ...« også en kraftig understregning heraf. Med denne kurs var der fra starten lagt op til en konfrontation med de ledende nazister i provinsen Slesvig-Holsten. Den blev imidlertid skærpet af to andre forhold. 
Efter at NSDAP ved rigsdagsvalget i juli 1932 havde fået 51,1\% af de afgivne stemmer i provinsen Slesvig-Holsten, havde nazisterne $\mathbf{i}$ september søgt at få kontrol med den grænsepolitiske organisation Schleswig-Holsteiner Bund. Stormløbet mislykkedes i første omgang. Med 67 stemmer bevarede W. Iversen, Munkbrarup, sin formandspost, mens udfordreren, Wilhelm Sievers, kun kunne mønstre 16 stemmer. Som en reaktion herpå bekendtgjorde Gauleiter Lohse, at nazisterne ville oprette deres egen grænsepolitiske organisation, og at de ville afbryde ethvert samarbejde med Schleswig-Holsteiner Bund. I denne strid blev W. Iversen og forbundet bakket op af pastor Schmidt - såvel bag kulisserne som offentligt. Et ydre udtryk herfor var det, at Wählerverein den 10. september 1932 i en resolution nok betegnede nationalsocialismen som "vort folks frihedsbevægelse«, men kraftigt understregede at grænsespørgsmål aldrig kunne være et partispørgsmål; samtidig blev mindretallets selvstændighed og modstanden mod dannelsen af nazistiske grupper i Nordslesvig atter betonet. 44

Efter at pastor Schmidt på denne måde havde krydset de slesvigholstenske nazisters spor, modtog han et par uger senere et brev fra Sievers. Det var en blanding mellem en fremstrakt hånd og en klar markering af, at NSDAP var fast besluttet på at føre kampen mod Schleswig-Holsteiner Bund til ende. Der er ikke noget der tyder på, at Schmidt benyttede anledningen til at knytte en nærmere kontakt til Sievers. Da Iversen, Munkbrarup, nogle måneder senere efter et voldsomt nazistisk pres alligevel nedlagde sit formandshverv, forsøgte Schmidt og ligesindede forgæves at formå admiral Hansen i Kiel til at kandidere. Det var således en resigneret pastor, der den 12. februar 1933 noterede $i$ sin skrivekalender: "Vel en ny formand $i$ S.H.B.«. Som ventet blev Wilhelm Sievers samme dag valgt til formand uden modkandidat. Hermed havde NSDAP sikret sig kontrollen med Schleswig-Holsteiner Bund. ${ }^{45}$

Den 7. marts kommenterede Schmidt begivenheden i et brev til en bekendt. Heraf fremgik det, at han anså valget af Sievers til formand som tåleligt, men han var bekymret for, om Sievers ville være i stand til i sine offentlige udtalelser at vise den nødvendige selvbeherskelse. Næsten som et apropos hertil skrev Schmidt et andet sted i brevet: "... De har helt ret $i$, at det nordslesvigske spørgsmål kræver arbejde på langt sigt, og ikke kan loses ved geniale feltslag. « ${ }^{46}$

Et par uger senere blev de bange anelser til vished. Den 24. marts 
kastede Wilhelm Sievers al selvbeherskelse over bord, da han i en bombastisk tale stillede krav om en grænserevision. Som tidligere nævnt blev det optakten til den såkaldte påskeblæst. Da det netop var et af de "geniale feltslag «, der stred fuldstændig mod pastor Schmidts grænsepolitiske koncept, søgte han sekunderet af sin hidtidige forbundsfælle, Ernst Schröder, at tage vinden ud af sejlene på de slesvigholstenske naziledere.

Den 29. marts skrev Ernst Schröder til gesandtskabsråd Duckwitz i Auswärtiges Amt og bad under henvisning til begivenhederne i Slesvig-Holsten om at få afstukket nogle klare retningslinjer for den tyske grænsepolitik. Det kunne ifølge Schröder f.eks. ske ved, at han lavede et interview med den tyske udenrigsminister Konstantin Freiherr von Neurath. Dagen efter svarede Duckwitz, at de centrale myndigheder ikke fandt det formålstjentligt, at udenrigsministeren lod sig "exponere" ved et interview. Men han kunne meddele, at statssekretær Funk ville skrive til Wilhelm Sievers og NSDAP's gauledelse i Altona, for at lægge en dæmper på dem.

Pastor Schmidt blev dog ikke beroliget ved disse efterretninger. Den 5 . april 1933 skrev han et langt brev til von Neurath. Han citerede her flere af Sievers' udtalelser og skrev, at det forekom ham tvivlsomt, om sådanne ytringer var $\mathrm{i}$ overensstemmelse med en klog udenrigspolitiks intentioner. "Sådan taler man, når man på forhånd har til hensigt at ydmyge en modstander: Du er lille, jeg er stor! Jeg bestemmer, du har at adlyde! Det svarer ikke til den holdning, som vi hidtil har indtaget ...«. Schmidt var bange for, at den slags udtalelser ville isolere Tyskland over for de nordiske lande. Han følte sig forpligtet til at forelægge von Neurath disse alvorlige betænkeligheder og spurgte samtidig, om den tyske regering følte sig stærk og fri nok til allerede nu at rejse spørgsmålet om en grænserevision over for Danmark. ${ }^{47}$

Samme dag som Schmidt skrev til den tyske udenrigsminister blæste pastor Peperkorn atter til storm i Ekernførde. Det var her han proklamerede, at den tyske nationalsocialisme som et lyn ville tage Nordslesvig i besiddelse. Talen blev refereret i bl.a. Hejmdal og Nordschleswigsche Zeitung. Det fik pastor Schmidt til den 7. april at rette en ny henvendelse til de centrale myndigheder - denne gang til lederen af NSDAP's nyoprettede Aussenpolitisches Amt, Alfred Rosenberg. Efter omtale af Peperkorns udtalelser blev Rosenberg spurgt lige ud, om han fandt det "... opportunt og nødvendigt under omgåelse og ignorering af den tyske organisation og førerskab i 
Nordslesvig at hidføre en storm over Nordslesvig«, som ville få den danske nationale modstand til at blusse op og i lang tid umuliggøre en tysk-nordisk forståelse. ${ }^{48}$

For at skabe klarhed blev Ernst Schröder samme dag bedt om "straks" at få konstateret i Berlin, om man der gik ind for Schmidts eller for Peperkorns grænsepolitiske linje. Det skete med en trussel om, at mindretalslederen ville nedlægge sit hverv, hvis det ikke lykkedes at få Peperkorns paroler afblæst. ${ }^{49}$ Schröder spildte ikke tiden. Den 19. april kunne han kort meddele, at von Neurath havde været bortrejst, men at Duckwitz ville tage sig af sagen i Auswärtiges Amt. I Berlin havde Schröder også opsøgt Alfred Rosenberg og gjort rede for hvordan han og pastor Schmidt så på sagen. Schröder og Schmidt var dog ikke de eneste, der havde henvendt sig til Rosenberg. Det havde Auswärtiges Amt også. Det bevirkede, at Rosenberg gav de slesvig-holstenske naziledere et pålæg om at afholde sig fra udfald mod Danmark. ${ }^{50}$

I slutningen af måneden rejste Schmidt selv til Berlin. Med sig i bagagen havde han en vished om, at de centrale myndigheder var ved at gyde olie på de oprørte vande. Den 27. april opsøgte han først Duckwitz i Auswärtiges Amt. Herpå var han i Reichspressestelle, hvor han talte med Alexander Bogs. Herefter spiste han middag med Werner Hasselblatt og havde sent om aftenen en samtale med Alfred Rosenberg. Man kan roligt gå ud fra, at temaet for samtalerne var det samme - og at Schmidt nu følte sig mere rolig. Efter et nyt besøg i Auswärtiges Amt den følgende dag indledte han tilbagerejsen og nåede den 29. april Tønder. ${ }^{51}$

Vel hjemme igen modtog Schmidt imidlertid et skarpt brev fra Wilhelm Sievers dateret den 27. april. Sievers indledte med at henvise til, at han og Peperkorn havde fået et telegram om, at de indtil videre skulle undlade al offentlig drøftelse af det dansk-tyske grænsespørgsmål. De havde opsøgt Alfred Rosenberg, men kunne her konstatere, at Ernst Schröder havde været der før dem. Over for Rosenberg havde Schröder truet med at han selv, regeringspræsident Wallroth og pastor Schmidt ville nedlægge deres hverv, hvis Sievers og Peperkorn ikke blev bragt til tavshed. "På grund af disse påstande“, skrev Sievers, "har hr. Rosenberg så anset det for nødvendigt først at sende os to et telegram for at undgå, at det skulle komme til yderligere mandatnedlæggelser. For mig gælder det nu, kære hr. pastor, at erfare fra Dem ..., om De har givet hr. Schröder til opgave at afgive den slags erklæringer over for hr. Rosenberg «. 


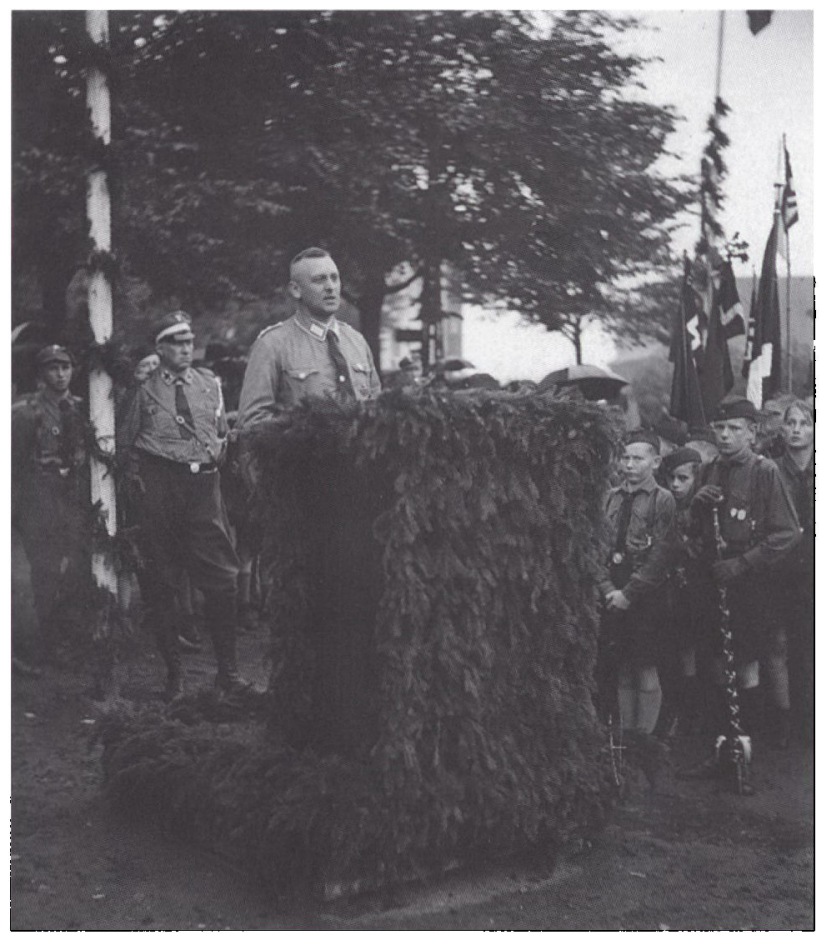

Dr. Wilhelm

Sievers taler ved

Hitler-Jugend-

stronet i Flensborg den 8. oktober 1933. Foto $i$

Dansk Centralbibliotek for Sydslesvig.

Sievers' fremstilling af de centrale instansers bevæggrunde til indgriben var her - bevidst eller ubevidst - meget ufuldstændig. Han kom ikke ind på de udenrigspolitiske problemer, som påskeblæsten havde givet den nye regering, og nævnte ikke, at han også fra anden side havde fået en henstilling om at indstille skydningen. Men Sievers havde med sit spørgsmål spiddet Schmidt m.h.t. dennes rolle i begivenhederne. Da mindretalslederen svarede næste dag, var det tydeligt, at han vred sig. Om det konkrete spørgsmål skrev Schmidt: »Jeg ved også, at hr. Schröder har været i Berlin og talt med hr. Rosenberg og andre. Hvad han har sagt helt nøjagtigt, ved jeg naturligvis ikke ...". Efter en længere omtale af andre forhold fortsatte pastoren: "... Jeg har ikke givet ham til opgave at fremsætte de af Dem citerede erklæringer, men det er nok muligt, at han af udtalelser fra min side har udledt, at jeg har beskæftiget mig med spørgsmålet, om situationen ikke engang kunne tvinge mig til at nedlægge mit mandat. De vil kende hr. Schröder godt nok til at vide, at han lejlighedsvis kan være noget temperamentsfuld ...«. Schmidt ville således ikke vedgå, 
at han selv havde bedt Schröder om at tage affære. Det er på denne baggrund forståeligt, han til sidst skrev, at han ikke ville give Schröder underretning »om vores brevveksling " og henstillede til, at Sievers ville stille sagen $i$ bero.

Hvis pastor Schmidt havde håbet, at dette svar ville tilfredsstille Sievers, tog han fejl. Det var anden gang, han havde krydset de slesvig-holstenske nazilederes spor. Alt taler for, at det kun yderligere kunne anspore dem til at bygge på andre kræfter inden for det tyske mindretal. Det var således ikke uden brod, da Sievers en måned senere $\mathrm{i}$ en ny tale proklamerede, at »... vi vil tænke på vore tyske brødre og pleje dem således, at de kan rejse sig med tysk væsen. Vi modtager enhver, der ærligt kommer til os, men på de såkaldte konjunkturpolitikere renoncerer vi gerne! « Der var dog en, som de tog til sig. Det var Ernst Schröder, der blev forsonet med de slesvig-holstenske naziledere - og meldte sig ind i NSDAP. Samtidig kom det til et brud mellem ham og pastor Schmidt. Resultatet var, at Schmidt stod mere isoleret end nogen sinde før, og at hans dage som leder af det tyske mindretal var talte.

\section{NSAN - det første hjemmetyske naziparti}

Den 15. april 1933 indeholdt Nordschleswigsche Zeitung en bekendtgørelse med overskriften "Nationalsozialisten «. Det var Nationalsozialistiske Arbeitsgemeinschaft Nordschleswig - i forkortet form NSAN - der her for første gang trådte offentligt frem $i$ avisens spalter. Datoen var næppe tilfældigt valgt. Den var sammenfaldende med udløbet af den frist, som pastor Peperkorn havde sat for tysksindedes udmeldelse af det danske nazistparti. I bekendtgørelsen blev de nazistiske arbejdsgrupper i Nordslesvig bedt om at tilslutte sig "centralen " på adressen Ramsherred 53 i Aabenraa. Samtidig lød der en opfordring til at danne nye grupper overalt i Nordslesvig. Enkeltpersoner kunne også henvende sig. Det skulle i alle tilfælde ske ved brug af følgende formel: "Vi undertegnede tyske nordslesvigere bekender os til NSDAP's idé og slutter os foreløbig sammen i et arbejdsfællesskab. Senere gennemorganisering forbeholdes. " Det var den samme ordlyd, som var blevet benyttet ved mødet på Saksborg Kro. Bekendtgørelsen sluttede med et »Nordschleswig Erwache!!«.

Bag dette skridt stod en 30-40 årig høj mand med et sølvhagekors på frakkeopslaget - som Berlingske Tidende skrev den følgende dag. 
Det var Jens Lorenzen. Han var født 1893, opvokset i Felsted og havde været flyverløjtnant under 1 . verdenskrig. I det civile liv havde han bl.a. været handelsmand og portier i Aabenraa. Det var i det sidstnævnte job, at han i folkemunde havde fået tilnavnet "Jens Godaw «, fordi han altid brugte denne hilsen over for gæsterne. I vejviseren for Aabenraa stod han opført henholdsvis som inspektør og som købmand. Ifølge den tyske konsul havde han tidligere engageret sig i Selvstyrebevægelsen og Lei- bevægelsen. I foråret 1933 var han leder af en lille gruppe nazister i Aabenraa, men havde hidtil ikke gjort sig politisk bemærket. Det var derfor, som Harboe Kardel senere skrev i sine erindringer, en homo novus der gik i gang med at organisere den hjemmetyske nazisme. Det fremgik også tydeligt af et møde, der nogle dage efter Lorenzens debut blev afholdt i Wählervereins afdeling i Sønderborg. Det blev her besluttet at forespørge, hvem der havde givet ham denne opgave. ${ }^{52}$

Efter eget udsagn var det den 13. april 1933, at Jens Lorenzen "modtog « sit nye hverv. Om opdraggiveren nøjedes han med over for pressen at udtale, at han folte det som en tillid, "... som tidligere krigskammerater viser mig «, og at arbejdet ville foregå efter de retningslinjer, som lederen af det nazistiske udenrigskontor, Alfred Rosenberg, "... har givet udtryk for «. Om det var Lorenzen selv, der havde taget det første skridt hertil, eller om initiativet var kommet sydfra, står hen i det uvisse. Det må i hvert fald antages, at der inden offentliggørelsen i Nordschleswigsche Zeitung var knyttet kontakt med ledende personer i provinsen Slesvig-Holsten. Det blev understreget af gårdejer Jep Schmidt, der var leder af en nyoprettet nazistisk ortsgruppe i Løjt Kirkeby, da han i maj stikordsagtigt skrev i et fortroligt notat: "Har fast forbindelse med N.S.D.A.P. har udnævnt en fører fra vore rækker «. ${ }^{53}$

Samme dag som Lorenzen offentliggjorde sin bekendtgørelse, udtalte han over for Berlingske Tidende, at NSAN ville rette et stød mod den organiserede tyske marxisme i Nordslesvig. Det var på denne konto, han forventede at vinde mange tysksindede arbejdere for den nye sag. Derimod stod det tyske nordslesvigske bourgeoisi, som Lorenzen kaldte det, mere modvilligt over for bevægelsen. Han ville ikke kamp, men forståelse med det danske nazistparti. Det var med dette mål for øje, at han en af de nærmeste dage ville opsøge Frits Clausen. På det punkt anslog Lorenzen således en mere fredsommelig tone end de slesvig-holstenske nazister havde gjort. Det var hans eget 
hjem, der skulle tjene som kontor for NSAN. På bordet var der et hagekorsbanner og en stabel "Dienstvorschriften " - som avisen noterede sig.

Jens Lorenzen regnede den 15. april med, at o. 300 personer havde tilsluttet sig centralen i Aabenraa. Men han lagde ikke skjul på, at den endelige organisation ikke var skabt endnu, lige som ledelsen ikke havde taget form. ${ }^{54}$ I praksis kom der til at gå flere måneder inden disse brikker begyndte at falde på plads. Medvirkende hertil var det, som en af Lorenzens støtter senere berettede, at der i de første måneder af NSAN's virke var "uendelige« stridigheder mellem de forskellige afdelinger om, hvem der skulle have ledelsen. Det var i tråd hermed, at den tyske konsul i april 1933 frygtede, at Lorenzens initiativ ville kollidere med de bestræbelser, som den før omtalte lærer Jacob Hansen udfoldede i Saksborg. ${ }^{55}$

Det lykkedes dog i første omgang Jens Lorenzen at sikre sin position som »Landesführer". Det skete i kraft af den opbakning, som han fik af de slesvig-holstenske naziledere. Ved at forhandle med ham som fører for den hjemmetyske nationalsocialisme »lånte« de, som en af de implicerede udtrykte det, deres autoritet til ham. Det var også Lorenzen, der sammen med pastor Schmidt fik sæde i det "lille forerråd «, som blev oprettet i sommeren 1933; med Gauleiter Hinrich Lohse, Wilhelm Sievers, pastor Peperkorn og Ernst Schröder på den anden side af bordet. ${ }^{56}$ Hermed var magtfordelingen også klart angivet. Det var således en fiktion, når den tyske konsul senere på året understregede, at "... den tysk-nationalsocialistiske bevægelse i det afståede område Nordslesvig udgør en af moderlandet uafhængig, selv ansvarlig organisation ...«, hvis fører kun nu og da var i forbindelse med Gauleiter Lohse og overborgmester Sievers med henblik på »rådgivning og vejledning ${ }^{5} .7$

Der er ingen tvivl om, at de slesvig-holstenske nazister betragtede NSAN som NSDAP's forlængede arm i Nordslesvig. Det var et udslag heraf, da Wilhelm Sievers i september 1933 på et møde med VDA og Schleswig-Holsteiner Bunds underførere skråsikkert udtalte sig om NSAN's opgaver i Nordslesvig og rigstyske organisationers økonomiske kontrol med mindretallet. ${ }^{58}$ Det var tilsvarende en resigneret pastor Schmidt, der kort efter i et brev konstaterede, at førerprincippet var blevet indført i Nordslesvig, »... men sådan, at Tysklands nationalsocialistiske parti bestemmer føreren, ikke sådan, at Nordslesvig vælger ham. Denne fører er foreløbig Lorenzen ...«. I samme ånde- 
dræt blev sidstnævnte omtalt som en bold i hænderne på de ledende folk i provinsen Slesvig-Holsten. ${ }^{59}$

Men Sievers \& Co. måtte gå på listesko. Berlins indgriben i "påskeblæsten « havde været et første ryk i tømmen. Efter flere modsat rettede signaler slog Hitlers stedfortræder, Rudolf Hess, et par måneder senere fast $i$ en kundgørelse, at rigsledelsen principielt nægtede at give partier uden for Tyskland nogen som helst ordrer eller råd, selv om de svarede til NSDAP eller var beslægtede hermed. Modsat kunne disse partidannelser heller ikke påberåbe sig NSDAP's autoritet og måtte i offentligheden ikke fremkalde indtryk af, at de stod i nogen som helst forbindelse med det rigstyske parti. Schleswig-Holsteiner Bund ville derfor nok, som Sievers nævnte i en tale den 25. maj, kæmpe om den tyske sjæl i Nordslesvig "nøjagtig som vi gør det hos os«; det skulle imidlertid foregå ved, at de forskellige distrikter i SlesvigHolsten enkeltvis skulle få personlig føling med »denne eller hin deroppe ${ }^{60}$

Det var den samme strategi han selv og andre partispidser benyttede sig af. F.eks. indtrådte Sievers og Peperkorn i bestyrelsen for Wohlfahrts- und Schulverein für Nordschleswig. Det var dog et problem for dem, at det hver gang vakte megen opsigt i den danske presse, når de passerede grænsen. Det var f.eks. tilfældet den 1. juli, da Wilhelm Sievers og Johann Peperkorn var i Aabenraa for at forhandle med Jens Lorenzen og besigtige Nordschleswigsche Zeitung. Tolv dage senere klagede den danske regering officielt herover i Berlin. Den uønskede rejseaktivitet blev betegnet som indblanding i indre danske forhold, der kun var egnet til at skabe uro i grænseområdet. Dette spotlight bevirkede i praksis, at de fleste møder mellem de hjemmetyske nazister og deres fæller i provinsen Slesvig-Holsten måtte foregå syd for grænsen. For at styrke kontakten - og sikre at bolden bevægede sig i den rigtige retning - kom assessor Hans Clausen Korff fra Flensborg derfor fra juli 1933 til at virke som de slesvigholstenske nazisters forbindelsesmand og forlængede arm i Nordslesvig. I praksis kom han til at virke som Jens Lorenzens grå eminence og blev af politiske modstandere beskyldt for selv at ville overtage ledelsen. Meget betegnende for afhængigheden af det slesvigholstenske bagland var det også, at NSAN i flere tilfælde benyttede Flensborg som ekspeditionskontor. ${ }^{61}$

En måned efter at Jens Lorenzen havde kaldt til samling om NSAN, skrev Hejmdal den 17. maj, at det nu kunne konstateres, at den tyske 
nazisme ikke havde fundet grobund i Nordslesvig. Det blev bl.a. begrundet med, at den tyske presse havde været påfaldende tavs om dette spørgsmål, og at man ikke hørte noget om oprettelse af nye afdelinger. Ifølge Hejmdal var det kun den helt unge generation, der var lydhør over for bevægelsen, hvorimod de tysksindede arbejdere og en stor del af borgerskabet stillede sig skarpt afvisende over for nazi-agitationen. Det skulle vise sig, at det var en forhastet konklusion. Nok gik det langsomt i starten, men de nye tanker bredte sig efterhånden som ringe $i$ vandet.

\section{NSAN i arbejde}

Samme dag som Hejmdal skrev sin nekrolog over den hjemmetyske nazisme, kunne Jydske Tidende berette, at Jens Lorenzen som et led i sin hvervning for NSAN fik udsendt brochurer gennem rigspropagandaledelsen af NSDAP. Lorenzen hævdede, at der ikke blev foretaget henvendelser til tysksindede tjenestemænd i Nordslesvig; avisen var dog af den formening, at der blev hvervet kraftigt for nazismen i de tyske privatskoler.

En af dem, der bidrog hertil, var Harboe Kardel. Han havde 19271929 været redaktør af Neue Tondernsche Zeitung indtil avisen gik ind. Efter nogle år som lærer i Flensborg og Kiel blev han i april 1933 leder af den tyske privatskole i Gråsten. Med sig havde han friske impulser fra Slesvig-Holsten. Dem gjorde han brug af, da der en måned senere blev dannet en NSAN-gruppe i Gråsten, der afholdt ugentlige aftenmøder $i$ hans hjem. Et ydre udtryk for denne virksomhed var det, at han inden sommerferien hængte et Hitlerbillede op i skolens store klasseværelse. Gråsten var ikke et isoleret fænomen. I begyndelsen af maj noterede Kardel i sin dagbog, at det nærved liggende Rinkenæs var et »Ausstrahlungspunkt« for den nye bevægelse. Han havde her selv været med til en »tysk aften «, hvor dyrlæge Jens Møller, Gråsten, begejstret havde berettet om sine oplevelser i Berlin den 1. maj. Der var ved denne lejlighed også blevet indviet en rød fane, der var smykket med en gul cirkel og et blåt hagekors. ${ }^{62}$

Andre steder gik det efter alt at dømme mere trægt. Det blev den 16. juni bekræftet af en stort opsat forsideartikel i Nordschleswigsche Zeitung med overskriften: »SA-mænd og partifæller«. Den var, som avisen bemærkede, tilsendt fra »ledende nationalsocialistisk side $\mathrm{i}$ Nordslesvig «. I svulstige vendinger blev der stillet krav om en græn- 
serevision, men samtidig blev de tysksindede nordslesvigere stærkt opfordret til at slutte sig til nationalsocialismen. Det blev således konstateret, at "... kun vi tyske heroppe er faldet i søvn. Det vækkende råb fra det nye opvågnede Tyskland har ikke været nok til at få alle på deres post.« For mindretallets vedkommende var det derfor ifølge artiklens forfatter ikke et "Deutschland Erwache", men der var brug for et »Nordschleswig Erwache!!!«. Alle SA-mænd og partimedlemmer i Nordslesvig skulle derfor være med til at samle alt, hvad der var tysk under hagekorset og hverve hver "sjæl«. Men opråb og taler inden for en mindre kreds havde kun succes, hvis man hele tiden ved demonstrationer, møder, skrifter og avisartikler med alle midler giorde den slesvig-holstenske befolkning opmærksom på dens pligt til at genvinde Nordslesvig. Det sidstnævnte lød som en optakt til Schleswig-Holsteiner Bunds store grænselandsdemonstration to dage senere i Rendsborg. Den blev dog kun en mat afglans af de slesvigholstenske nazilederes store fremstød tidligere på året.

Fra sommeren 1933 blev NSAN mere synlig. I juli blev der afholdt grænselands-skolingsdage på Knivsbjerg med foredrag af "fremragende repræsentanter « fra det nye Tyskland. I august blev der indledt en række store nazimøder. Den 16. august fandt der en "Kundgebung « sted i Sønderborg med o. 200 deltagere. Antallet var omtrent det samme fire dage senere, da ortsgruppen i Aabenraa havde faneindvielse. Ved samme lejlighed blev Chr. Bruhn indsat som ortsgruppeleder. En af de tilstedeværende, Harboe Kardel, noterede bagefter i sin dagbog, at Jens Lorenzen var kommet ind i Teaterhotellets sal iført brun skjorte i spidsen for 12 faner. Den brune skjorte blev dog ikke kun brugt ved festlige lejligheder; ifølge Kardel blev Lorenzen ofte set $i$ byens gader iført denne mundering hilsende med hævet arm. ${ }^{63}$

Vestpå begyndte partiet også at vinde frem. I juni blev Jejsing gjort til "støttepunkt «. I juli blev der oprettet en ortsgruppe i Højer med en tilknyttet »blok « $\mathrm{i}$ Daler. I september blev der dannet en ortsgruppe i Løgumkloster og et støttepunkt i Øster Højst. I oktober var man så vidt, at der blev udpeget en kredsleder for Tønderområdet. I november blev Ballum-Randerup gjort til en »blok«, og i december kom turen til Rudbøl, Abel og Sæd-Ubjerg. Hertil kom ortsgruppen i Tønder, hvis oprettelsestidspunkt officielt blev henregnet til det tidligere omtalte møde i marts 1933, hvor 27 hjemmetyskere havde skrevet under på, at de ville kæmpe for det nye Tyskland. ${ }^{64}$ 


\section{Havne-Uroen i Aabenraa. \\ Nazister losser Resten af "Maja Ladning! \\ Tidligt i Morges gik 8 tyske Nazister fra Aabenraas Omegn i Gang med Losningen, der ventes tilendebragt i Eftermiddag. \\ Politiforstærkning fra Sønderborg og Tønder.}

Aabenraa, Tirsdag.

K OMmunisterne, som endnu I saa sent som i Nat mente at være Situationens Herrer m. H. t. Striden om "Maja «s Losning, fik i Morges en alvorlig Forskrækkelse. Kl. 6 var otte tyske Nazister fra RisRødekro-Egnen gaaet i Gang med at losse Resten af "Majaus Last. Arbejdet gik raskt fra Haanden, og Betjentenes Antal var forøget betydeligt. Fra Sønderborg var i Morges kommet 20 Betjente og fra Tønder 10, saa Overbetjent $\mathrm{T}$ harning i Dag raader over en Styrke paa 40 Mand.

Losningen ventes at være tilendebragt i Eftermiddag. "Maja«s Kaptajn har truffet alle Forberedelser til, at Skibet, saa snart den sidste Sæk er hejst op, og Nazisterne er kommet i Land, kan stikke til Søs.

\section{Nazisterne griber ind:}

6)Medens Kaptajnen pa s Maja var ved at fortvivle over sin pinlige Stilling og i Gaar truede Ladningeng Modtager med at sejle, greb Nazisterne ind. Mekaniker J ens $\theta \cdot n$, Callesensgade, som fornylig er gaaet over fra de danske-Nazisters Rækker til de tyske, skaffede, da Føreren Jens $L$ orenzen nægtede at tage sig af Sagen, Arbejdskraft tilveje, idet han fik fat 1 otte Medlemmer af den tyske nationalsocialistiske

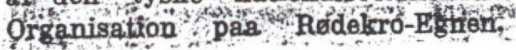

Gennem mere end en uge forst $i$ august 1933 berettede dagbladet Hejmdal udforligt om det hagekorssmykkede skib "Maja», som danske arbejdere nægtede at losse. Her udsnit af artiklen den 8. august 1933. 
Denne kamp fik i august 1933 et ydre udtryk ved den såkaldte "Maja-sag" i Aabenraa. Maja var et tysk skib, som danske arbejdere havde nægtet at losse på grund af dets hagekorsflag. Et hold frivillige havde losset halvdelen af skibet under politibeskyttelse, men herpå nedlagde også de arbejdet. Det blev i stedet 8 hjemmetyske nazister fra Rise Hjarup under ledelse af mekaniker I. M. Jensen, der under stor mediebevågenhed og øget politibeskyttelse gjorde arbejdet færdigt. I. M. Jensen var kort tid forinden udtrådt af det danske nazistparti og havde meldt sig ind i NSAN. Her blev han leder af "Standarte I« og havde titel af Sturmbannführer. Det var i denne egenskab, at han var gået $i$ aktion på havnen i Aabenraa. ${ }^{65}$

Efter rigstysk forbillede blev der dannet flere SA-afdelinger. F.eks. havde "Sturm Düppel« den 21. september faneindvielse i Sønderborg under udfoldelse af et stort ceremoniel. Med deltagelse af 600 »folkefæller « fra alle nazistiske grupper i Nordslesvig indledte man med sangen "Volk ans Gewehr«; herpå var der taler, faneindvielse, aflæggelse af troskabsed, samt afsyngelse af Horst-Wessel-sangen og Tysklandssangen. Foruden en "marinestorm « rådede det hjemmetyske SA også over en "motorstorm ". I Tønder blev der i begyndelsen af december 1933 først oprettet en "SA-efterretningsstorm" (SA-Nachrichten-sturm), men den blev en måned senere omdannet til en "motorstorm « og fik efter et politiforbud det mere tandløse navn Slesvigsk Automobilklub. Uniformer modtog det hjemmetyske SA fra fællerne syd for grænsen, men på grund af uniformsforbudet måtte øvelser $\mathrm{i}$ fuld mundering henlægges til om natten eller tidligt om morgenen. ${ }^{66}$

Den 23. september 1933 sendte Jens Lorenzen en fortrolig skrivelse til en kreds af sine nærmeste støtter. Det blev her konstateret, at NSAN's organisation nu var opbygget »i grundtrækkene«. Hvervning og agitation skulle fremover foregå på et kulturelt og økonomisk grundlag. Til det formål skulle der oprettes et særligt sagkyndigt råd. De blev derfor bedt om at komme til et møde i Aabenraa fem dage senere. Vigtigheden heraf blev understreget ved en passus om, at fremmøde var "ubetinget pligt «, og at udeblivelse kunne få konsekvenser for den pågældende. Det var samtidig en demonstration af, at førerprincippet blev taget meget bogstaveligt. ${ }^{67}$

Det var som en følge heraf, at NSAN den 28. september oprettede et "politisk sagkyndigt råd " for kultur- og erhvervsforhold. Det bestod foruden Jens Lorenzen af Jep Schmidt, Løjtkloster, Dr.Clausen, Haderslev, Andreas Schau, Tønder, Ed.Eckwerth, Aabenraa, Chr. Lei, 
Ullerup, Hans Berg, Løjtkloster, Christian Feddersen, Ladegård, Frederik Christensen, Aabenraa og Hans Clausen Korff. De tilhørte alle "med en undtagelse«, som Clausen Korff skrev et par dage senere, "den unge generation af den nationalsocialistiske bevægelse i Nordslesvig «. Rådet havde to opgaver. Det skulle rådgive landsføreren fra sag til sag i alle politiske, kulturelle og okonomiske anliggender, og det skulle tilvejebringe "det åndelige og propagandistiske grundlag « for kampen mod danskheden. Medlemmerne af rådet skulle også fungere som talere i forsamlinger og ved skolingsaftner. På længere sigt skulle de endvidere virke gennem pressen og ved udgivelse af skrifter.

Samme dag som det nye råd blev nedsat vedtog det nogle retningslinjer for NSAN's politiske virke. Indledningen havde følgende ordlyd: "Vi ser 3 opgaver for os: 1. Omdannelsen af tyskheden i Nordslesvig til en sluttet nationalsocialistisk blok. 2. Nordslesvigs genvindelse for Tyskland ved genskabelsen af Slesvigs enhed. 3. Den indre, åndelige løsning af det nordslesvigske spørgsmål.« Det skulle alt sammen gøres inden for rammerne af tysk udenrigspolitik.

Løsningen af den første opgave skulle ske ved, at medlemmer af NSAN overtog ledelsen af Wählerverein. Ifølge rådet var det kun et nazificeret tysk mindretal, der kunne tage kampen op mod danskheden. NSAN anså i den forbindelse ikke den danske marxisme som ærlige modstandere på samme måde som danske nationalsocialister og konservative - formentlig fordi de førstnævnte havde en anden opfattelse af det nationale. Men de var alle mindretallets fjender. Det var ud fra en overbevisning om, at det var umuligt med held at føre en politisk kamp, hvis man samtidig havde venskabelige forbindelser med modstanderen. Konklusionen herpå var, at NSAN havde valgt "... den ubetingede kamp og bryder bevidst med den hidtidige forståelses politik «.

Efter markeringen af denne klare antidanske holdning, blev det om det ovenfor nævnte punkt 2 udtalt, at NSAN i overensstemmelse med Hitlers udenrigspolitiske retningslinjer var imod en voldelig grænserevision. I stedet skulle kampen føres med åndelige våben. En grænserevision kunne således finde sted på to måder. Enten ved at den erkendelse bredte sig, at Danmark ikke kunne beholde Nordslesvig af økonomiske grunde - "... hvis det ikke selv vil synke i afgrunden“, eller ved at vinde blakkede og dansksindede for tyskheden.

Som helhed var der ingen forskel på denne grænserevisionsrecept 
og de kandestøberier, som pastor Schmidt tidligere havde udfoldet, men tankegodset var mere ideologisk betinget. NSAN var således af den opfattelse, at det i princippet var muligt at vinde alle nordslesvigere, fordi de "... foruden det danske blodtilskud har tysk blod i årerne«. Derfor kunne de, som det blev nævnt, også ud fra en nationalsocialistisk synsvinkel blive tyske, når de fuldt og helt bekendte sig til tyskheden. Det var ifølge NSAN også den eneste måde at løse det nordslesvigske spørgsmål på. Hermed blev det klart markeret, at de dansksindede i Nordslesvig ikke skulle gore sig mange illusioner om et liv som nationalt mindretal i et kommende Stortyskland. Der ville blive tale om en kamp på langt sigt, "... som ikke vi, men vore efterkommere vil fuldføre . Men kampen om de blakkedes og de dansksindedes sjæle skulle indledes med det samme og med alle midler. Afslutningsvis blev det udtalt, at NSAN ville påtage sig selv at føre den kulturelle kamp; derimod håbede partiet på rundhåndet økonomisk hjælp fra Tyskland til støtte for bevarelsen af jord på tyske hænder. 68

De her nævnte tanker blev uddybet, da Clausen Korff en måned senere fra sin "Geschäftsstelle“ i Flensborg udsendte NSAN's første »førerbrev«. På 11 tæt skrevne sider blev de lokale førere nærmere orienteret om partiets politiske linje. Nok gjaldt det om at vinde alle tysksindede for nazismen, men hvervearbejdet skulle især koncentrere sig om bønder og arbejdere. Det var en hovedopgave at skabe gunstige forudsætninger for, at Tyskland på et senere tidspunkt kunne stille krav om en grænserevision. I den forbindelse blev det hævdet, at befolkningen i Nordslesvig havde "tre slags blod «: rent dansk, rent tysk og blandet. Det var afgørende for tilbøjeligheden til at lade sig påvirke af den ene eller den anden kultur. Da det kun var et lille mindretal, der havde rent dansk blod i årerne, var der ifølge Clausen Korff gode muligheder for at vinde befolkningen for tyskheden. ${ }^{69}$

Disse overvejelser var i det »strengt fortrolige« førerbrev kun forbeholdt en snæver kreds. De kunne ifølge samme hjemmelsmand ikke omtales i mindretallets presse med tilstrækkeligt eftertryk på grund af Tysklands vanskelige udenrigspolitiske stilling. Medvirkende hertil var dog også, at NSAN endnu ikke havde fuld kontrol med Nordschleswigsche Zeitung. Det var med henblik herpå, at Jens Lorenzen og Ernst Schröder arbejdede på at få avisens mangeårige redaktør, Julius Kähler, erstattet med Harboe Kardel. Det lykkedes dog først med virkning fra den 1 . januar $1934 .^{70}$ 


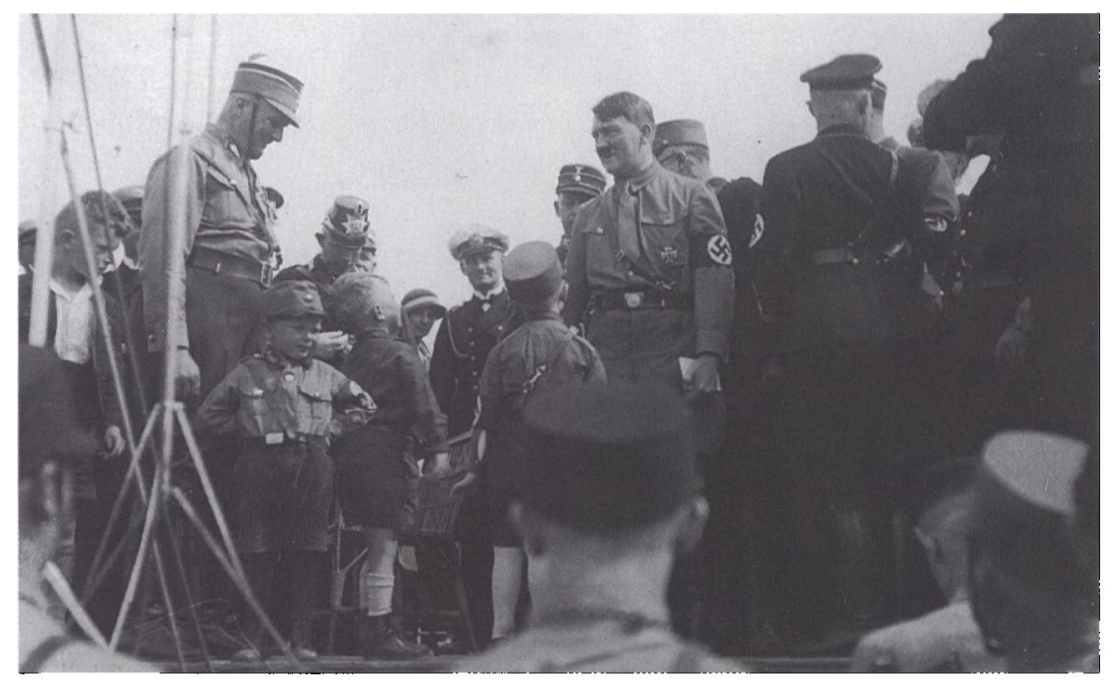

Adolf Hitler fotograferet ved en S.A. opmarch $i$ Kiel den 7. maj 1933.

I mellemtiden havde NSAN intensiveret sin hvervekampagne. Den 9. september 1933 bragte Nordschleswigsche Zeitung en proklamation fra landsdelens »Amtswalter". Her blev det udtalt, at hjemmetyskerne som en del af det tyske folk ikke måtte tro, at de havde lov til at forholde sig passive. Det var heller ikke nok, at man ved passende lejligheder hævede armen og sang med på Horst-Wessel-sangen. "Nej, her har enhver at være med. Det folk, som enhver har at tjene, er det tyske folk i Nordslesvig, det tyske folk i din by, i din landsby. Her har enhver at stille sig til rådighed.« En måned senere kunne Hejmdal afsløre, at der også blev brugt mere direkte metoder. Avisen offentliggjorde et spørgeskema, hvor de to første spørgsmål havde følgende ordlyd: »1) Er De i SA eller i SA-reserven? Hvilken afdeling tilhører De, og hvilken tjenestegrad har De? 2) Hvis De ikke er i SA, har De da et hverv inden for partiet og hvilket? Hvis ikke, hvorfor stiller De ikke deres arbejdskraft til rådighed for vor bevægelse?« Herpå fulgte flere andre nærgående spørgsmål og en erklæring om, at den pågældende ville støtte NSAN økonomisk. ${ }^{71}$

\section{Den første nazificerings omfang}

Agitationen forblev ikke uden virkning. I slutningen af september 1933 skrev konsul Kühne i en indberetning til Auswärtiges Amt, at 
den nationalsocialistiske bevægelse vandt mere og mere frem inden for mindretallet. Med Jens Lorenzen som kilde kunne han oplyse, at NSAN for kort tid siden havde udstedt medlemskort nr. 4.000, hvilket var 5 gange så mange medlemmer som i Schleswigscher Wählerverein. Det var ifølge konsulen et meget glædeligt resultat, når det blev taget $\mathrm{i}$ betragtning, at det kun var omkring fem måneder siden NSAN var blevet oprettet. Alene i Tinglev skulle der være 180 hjemmetyske SA-mænd. Tilsvarende glædede konsulen sig over, at $0.90 \%$ af samtlige SA-mænd i Nordslesvig var arbejdere, hvoraf flertallet tidligere havde bekendt sig til det danske socialdemokrati. Der var også dannet kvindeafdelinger. Ifølge konsulen boede de fleste hjemmetyske nazister i Aabenraa, Sønderborg og Tønder amter. Partiet ville nu bestræbe sig på at få fodfæste i Haderslev amt. For at undgå udvisninger var man mest interesseret $i$, at det var danske statsborgere, der meldte sig ind NSAN. Konsulen kunne endvidere berette, at der var et fredeligt forhold til det danske nazistparti, men en klar afgrænsning. ${ }^{72}$

Oplysningen om at halvdelen eller flertallet af SA-mændene tidligere havde bekendt sig til det danske socialdemokrati kan ikke kontrolleres - men er næppe sandsynlig. Tilsvarende er det muligt, at medlemstallet var overdrevet. I begyndelsen af august fik Harboe Kardel i hvert fald medlemsnummer 834, da han meldte sig ind i NSAN. I slutningen af august kunne rektor Koopmann og Gäde berette, at der var 3.000 medlemmer. Tre uger senere var dette tal ifølge Jens Lorenzen vokset til $4.000 .{ }^{73} \mathrm{Hvis}$ tallene skal tages for pålydende, var der tale om en eksplosiv vækst.

Der er imidlertid ingen tvivl om, at nazificeringen nu kunne mærkes inden for mindretallet. I begyndelsen af september havde NSAN's kredsleder i Sønderborg, Ed. Eckwerth, foreslået, at samtlige tyske foreninger skulle oplose sig selv og slutte sig sammen i en enhedsorganisation, der tog sig af alt lige fra kultur, sport, sociale forhold, valg, ungdom og skoler til fester. Det var ud fra en opfattelse af, at »... man .i dag ikke længere kan skille politik og kultur ...«. Dannelsen af den nye forening skulle ske, som det blev fremhævet, efter totalitets- og førerprincippet. Så vidt kom det ikke, men flere tyske foreninger - herunder borger- og musikforeninger - blev opslugt af det nyoprettede Bund für deutsche Kultur, der gennem koncerter, teater, foredrag og film skulle sammensvejse mindretallet til et "nationalsocialistisk kulturfællesskab«. Tilsvarende gik det med Pfadfinder og 


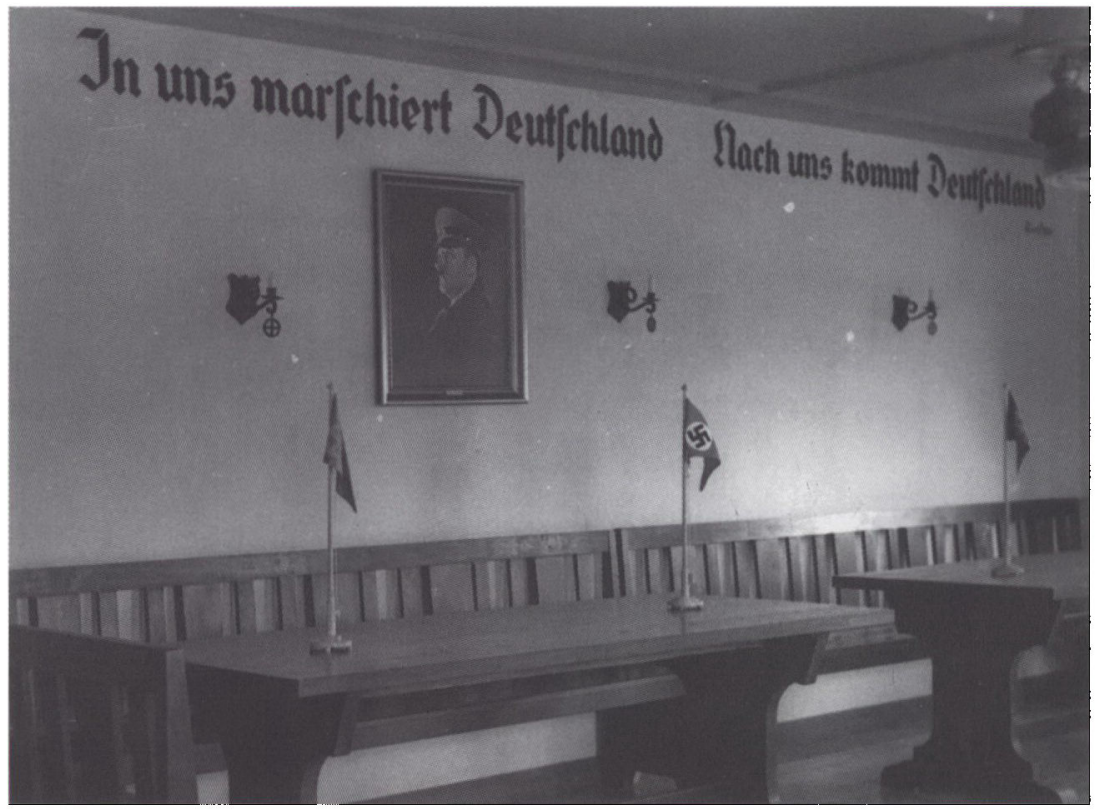

Efter "Nordslesvigs opvågnen«: Interiør $i$ "Max Valentiner-Heim « $i$ Sønderborg 1940. Foto: Deutsches Museum Nordschleswig.

Wandervogel, som smeltede sammen med det i sommeren 1933 nyoprettede Deutsche Jungenschaft Nordschleswig, der blev en hjemmetysk pendant til det rigstyske Hitlerjugend. Deutscher Jugendverband Nordschleswig fulgte trop idet hovedparten af medlemmerne også var aktive inden for NSAN. I andre foreninger begyndte nazisterne også at gøre sig gældende. ${ }^{\mathbf{7 4}}$

Denne udvikling kunne mærkes inden for mindretallets politiske organisation Schleswigscher Wählerverein. Den 3. oktober 1933 var der generalforsamling i Aabenraa-afdelingen. Det førte til, at den gamle bestyrelse blev erstattet af nye kræfter i skikkelse af bl.a. SAføreren I. M. Jensen og NSAN's ortsgruppeleder Chr. Bruhn. I Haderslev-afdelingen måtte, som Grænsevagten skrev, den gamle formand vige sædet for den »rettroende« dr. Otto Meyer. Samtidig blev antallet af styrelsesmedlemmer sat ned fra 7 til 5; heraf var det kun to af de gamle, der fortsatte. I Sønderborg var der åbenbart tale om en virkelig paladsrevolution; her gik hele den gamle bestyrelse og det endda midt under mødet! Tilsvarende gik det andre steder - mere 


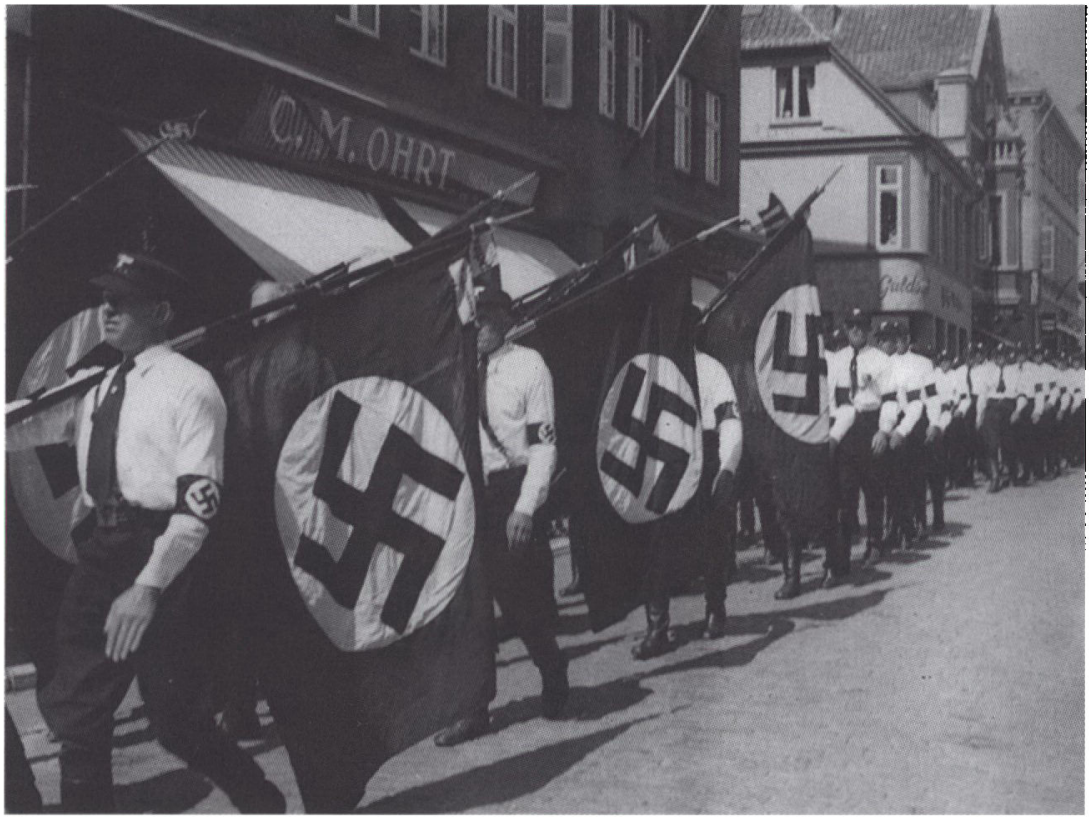

Efter »Nordslesvigs opvågnen «: Schleswigsche Kameradschaft Sonderburg marcherer den 29. juni 1941. Foto: Deutsches Museum Nordschleswig.

eller mindre frivilligt. Hermed havde de hjemmetyske nazister overtaget kontrollen med Wählerverein.

Nazificeringen af det tyske mindretal kom dog ikke til at forløbe glat og ubesværet. I efteråret 1933 blev de første sprækker synlige inden for NSAN. Det var med henblik herpå, at Oberschulrat Eduard Edert, der havde spillet en central rolle i opbygningen af det tyske privatskolevæsen i Nordslesvig, den 20. oktober 1933 gav følgende karakteristik af situationen i et brev til en bekendt:

»Den efter tysk mønster foretagne ensretning af det tyske mindretals organisationer er kun delvist blevet gennemført. Det er et spørgsmål, om den kan gennemfores helt, da modstanden jo ikke som i Tyskland kan brydes ved statens magt og den offentlige mening. Tværtimod har enhver, der bliver fortrængt fra sit tillidshverv ret til at kritisere, give sin utilfredshed luft over for danske bekendte, så at den danske presse er bedre underrettet end før om den nuværende tilstands utilstrækkelighed. Hovedfejlen består i, at der ikke findes en virkelig fører i Nordslesvig, der i kraft af sin personlighed udøver den nødvendige autoritet. Den gamle fører har de ikke mere, den nye 
har de endnu ikke. Der mangler en fælles vilje og en klar parole. Jo mere ledelsen savnes, jo mere anmassende gebærder sig naturligvis de små høvdinge “. ${ }^{75}$

Det blev starten på en langvarig og opslidende kamp mellem flere nazistiske grupperinger, som først blev afsluttet ved udgangen af 1938. Det var i dette virvar at pastor Schmidt flere gange søgte et comeback som leder af mindretallet - dog uden held. Det var imidlertid ikke en strid for eller imod nazismen, men om hvem der skulle være fører.

\section{NOTER}

Forkortelser:

ADVN Archiv deutsche Volksgruppe Nordschleswig

BP Bundesarchiv, Potsdam

LA Landsarkivet, Aabenraa

RA Rigsarkivet

S.-H.L. Schleswig-Holsteinisches Landesarchiv

1. Nordschleswigsche Zeitung 31.1., 1.2.4.2, 6.2., 9.2. og 17.2.1933.

2. Ibid. 27.2.1933.

3. Ibid. 28.2., 1.3.-1.4.1933.

4. Ibid. 13.3., 20.3-23.3.1933.

5. Ibid. 19.4.1933.

6. Ibid. 19.4.1933.

7. Nordschleswigsche Zeitung nr. 1147 (LA).

8. Deutscher Volkskalender für Nordschleswig 1934, p. 94.

9. Deutscher Schulverein für Nordschleswig, nr. 135 brev 16.3.1933 (LA).

10. Nordschleswigsche Zeitung 25.3.1933, Lecker Anzeiger referat efter Grænsevagten $X V$ pp. 141-142.

11. Nordschleswigsche Zeitung 27.3.1933.

12. Se f.eks. Nordschleswigsche Zeitung 28.3., 7.4. og 10.4.1933.

13. Nordschleswigsche Zeitung 7.4., 21.4. og 25.4.1933.

14. Peter Kr. Iversen: Lærer Alfred Torps optegnelser fra et ophold i Tønder, III, Sønderjyske Årbøger 1965 p. 77.

15. Sonderborg Socialdemokrat 7.4.1933.

16. Nordschleswigsche Zeitung 3.4.1933.

17. Der Schleswig-Holsteiner 1933, p.
107. Nordschleswigsche Zeitung nr. 1131, 1929-37 Protokol for "Ausschuss des Aufsichtsrates" 27.4.1933 (LA). Abt. 399.71 nr. 101, resolutioner 9.4.1933 (S.-H.L.). Meddelelsen i Schleswig-Holsteinische Tageszeitung om at Hitlerjugend var "sprunget" over grænsen er gengivet i Nordschleswigsche Zeitung 8.4.1933.

18. Nordschleswigsche Zeitung 8.4. og 11.4.1933. Der Schleswig-Holsteiner 1933, pp. 107-108.

19. Abt. 399.71 nr. 140 , brev $15.4 .1933 \mathrm{fra}$ Kähler til Schmidt (S.-H.L.).

20. 61 Sti 1 Deutsche Stiftung, Nordschleswig nr. 21 p. 384 (BP). Aus der Geschichte der NSDAP-N Kreis Tondern 1933-1943, pp. 2, 50-51 (1943). Oplysningerne om Jef Blumes skoletid i Nibøl bygger på et interview med forfatteren 20.4.1985. Om andre hjemmetyskeres tilslutning til nazismen se også Chr. M. Carstensen: Nordschleswigs Sendung im grossgermanischen Reich, p. 4 (1942).

21. Henning Poulsen: Besættelsesmagten og de danske nazister, pp. 23-27 (1970). Malene Djursaa: DNSAP danske nazister 1930-45, I pp. 15-18 (1981). Åbenrå bys historie, III p. 190 (1974). John T. Lauridsen: Frits Clausen og »førerkuppet« i DNSAP i 1933, Sønderjyske Årbøger 1997 pp. 183ff.

22. H. Becker-Christensen: Det tyske mindretal i Nordslesvig 1920-1932, II pp. 299-303 (1990). Om tysksindedes tilslutning til DNSAP se også Chr. M. Carstensens udsagn $i$ "Nord- 
schleswigs Sendung im grossgermanischen Reich « p. 27.

23. Statistiske Meddelelser 4. rk. 92. bind 1. hæfte p. 86.

24. Deutscher Schulverein für Nordschleswig nr. 128, brev 8.12.1932 (LA). Auswärtiges Amt nr. 118 D 649853 (RA).

25. Statistiske Meddelelser 4. rk. 92. bind 1. hæfte pp. 82-86. Om Slesvigsk Partis deltagelse $\mathrm{i}$ folketingsvalget 1932 se Henrik Becker-Christensen op.cit. II pp. 282-297.

26. Nordschleswigsche Zeitung 11.7.1932.

27. Aus der Geschichte der NSDAP-N Kreis Tondern 1933-1943, p. 2 (1943). Nordschleswigsche Zeitung citerede 8.4.1933 Schleswig-Holsteinische Tageszeitung for en artikel om, at Hitlerjugend på et tidligere tidspunkt havde forlagt sit område-kontor fra Jübeck til Flensborg for bedre at kunne bearbejde Nordslesvig. Resultatet skulle foruden Tønder også være selvstændige »Standorte i Haderslev og Aabenraa.

28. 61 Sti 1 Deutsche Stiftung, Nordschleswig nr. 21 p. 384 (BP). Ein Kampf um Nordschleswig. 5 Jahre NSAN, pp. 39-40 (1938). Harboe Kardel: Grenzlandmelodie in Dur und Mol, p. 74 (1975). Det skal bemærkes, at der er forskellige udsagn om oprettelsestidspunktet. Ifølge Chr. Bruhn var det i sommeren 1932, mens NSAN's parti-historie og Kardel skriver, det var $\mathrm{i}$ slutningen af året.

29. Auswärtiges Amt nr. 118 D 649851 (RA).

30. Auswärtiges Amt, Kult. Pol. VI A. nr. 170 D 521994 (RA). Harboe Kardel: Fünf Jahrzehnte in Nordschleswig, p. 109 (1971). Aus der Geschichte der NSDAP-N Kreis Tondern, p. 2.

31. Nordschleswigsche Zeitung 2.3., 3.3., 27.3. og 30.3.1933.

32. Ibid. 28.3.1933.

33. Ibid. 29.3.1933.

34. Ibid. 4.4.1933. Ein Kampf um Nordschleswig. 5 Jahre NSAN, pp. 12-13 (1938).

35. Hejmdal 6.4.1933. Referatet her er på enkelte punkter mere udførligt end det i Der Schleswig-Holsteiner 1933 pp. 106-107 aftrykte.
36. Pastor Schmidts skiftende opfattelse af grænserevisionskravet er behandlet $\mathrm{i} \mathrm{H}$. Becker-Christensen op.cit. II pp. 58-98, 269-281.

37. Schmidts politiske opfattelse er udferligt omtalt i op.cit. I pp. 122-127.

38. Ibid. II pp. 300-301.

39. Brev 7.3.1933 fra pastor Schmidt til Dr. Ewoldt, N II 2.1-2.24 (ADVN).

40. Deutscher Volkskalender für Nordschleswig 1934, pp. 19-24.

41. Abt. 399.71 nr. 183 , brev 8.2.1931 fra pastor Schmidt til E. Gross (S.-H.L.).

42. Nordschleswigsche Zeitung 17.3. og 18.3.1933.

43. Abt. 399.71 nr. 183, resolution med ledsagende skrivelse 5.4 .1933 (S.H.L.),

44. Resolutionen er gengivet i Harboe Kardel: Fünf Jahrzehnte in Nordschleswig, p. 112. Udkast hertil findes i pastor Schmidts arkiv Abt. $399.71 \mathrm{nr}$. 122 (S.-H.L.). Her findes også en rundskrivelse dateret den 14.9.1932 fra Schleswig-Holsteiner Bund om det passerede.

45. Abt. 399.71 nr. 122, brev 20.9.1932 fra Sievers til Schmidt (S-H.L). Ibid. breve 15.12.1932 fra $W$. Iversen til dr.Petersen. Ibid. brev 3.2.1933 fra pastor Schmidt til admiral Hansen. N II 1.3. Tagebuch 12.2.1933 (ADVN).

46. N II 2.1-2.4 brev 7.3.1933 fra pastor Schmidt til dr. Ewoldt (ADVN).

47. N II 2.1.-2.4 brev 5.4.1933 fra pastor Schmidt til Neurath (ADVN). Med Ernst Schröder som budbringer nåede brevet frem til Auswärtiges Amt. Den 19. april kunne han berette, at Neurath var bortrejst, men at Duckwitz ville tage sig af sagen (Ibid. brev 19.4.1933 fra Ernst Schröder til pastor Schmidt (ADVN)). Den 22.6.1933 videresendte Duckwitz pastor Schmidts brev til den tyske gesandt i Kobenhavn med følgende ord: "Vedlagt ... en skrivelse, som Schmidt-Wodder for længere tid siden sendte til rigsministeren. Den er først $i$ disse dage igen dukket op på mit skrivebord. I mellemtiden er indholdet jo blevet overhalet af udviklingen. Skal over for Schmidt bekræfte, at Neurath er underrettet« (Auswärtiges Amt nr. 113 D 648989 (RA)). 
48. Peter Hopp og Carsten Mogensen: Ostersturm/Påskeblæsten 1933, pp. 65-67 (1983).

49. Ibid. p. 107.

50. N II 2.1.-2.4 brev 19.4.1933 fra Ernst Schröder til pastor Schmidt (ADVN)).

51. N II 1.3. Tagebuch 27.4.-29.4.1933 (ADVN).

52. Berlingske Tidende 16.4.1933. Auswärtiges Amt nr. 118 D 649998 (RA). Harboe Kardel: Grenzlandmelodie in Dur und Moll, p. 75. Åbenrå bys historie, III p. 191. Nordschleswigsche Zeitung 21.4.1933. Aabenraa Vejviser 1932 og 1933.

53. Berlingske Tidende 16.4.1933. Optegnelser maj 1933 (Jep Schmidt privatarkiv). Grænsevagten hævdede i januar 1934 (p.15) uden kildeangivelse, at man maf visse grunde« havde måttet opgive at udpege lederen af den tyske privatskole i Sønderborg, Hans Martin Johannsen som "Landesführer«, og i stedet havde kåret Jens Lorenzen. Der er i det gennemgåede kildemateriale ikke fundet belæg for Johannsens kandidatur. Hvis det har sin rigtighed, kan de "visse grunde" være, at Johannsen var tysk statsborger og dermed kunne udvises, hvis han blandede sig i politik. Lorenzen var derimod dansk statsborger.

54. Berlingske Tidende 16.4.1933. Uden at der behøver at være en sammenhæng, svarer Lorenzens skøn over indmeldte til det antal hjemmetyskere, som Ernst Schröder $i$ august 1932 fik oplyst havde tilsluttet sig NSDAP i provinsen Slesvig-Holsten.

55. Auswärtiges Amt nr. 118 D 649998 (RA). Ibid. nr. 112 D 648955 (RA). Hejmdal talte også 17.5 .1933 om en splittelse inden for nazisternes rækker.

56. Troels Fink: Sønderjylland siden genforeningen i 1920, p. 102 (1955).

57. Auswärtiges Amt nr. 118 D 649872 (RA).

58. Abt. 399.71 nr. 127 "Sitzung der Unterführer des VDA/SHB in Kiel am 26. september 1933" (S.-H.L.).

59. Abt. $399.71 \mathrm{nr} .183$ brev 10.10 .1933 til H. M. Johannsen (S.-H-L.).

60. Rudolf Hess' kundgørelse er aftrykt $i$
Grænsevagten 1933 p. 267. En afskrift findes også i Abt. 399.71 nr. 291 (S.H.L.). I et brev til Werner Hasselblatt 10.7.1933 kommenterede pastor Schmidt den næunte kundgørelse, men han mente ikke den var helt "gennemsigtig". Han havde bedt pastor Peperkorn om en udlægning af teksten, men havde ikke fået noget svar - ifølge Schmidt fordi de slesvigholstenske nazister onskede, "at alt er svævende" (Abt 399.71 nr. 289 (S.H.L. ). Sievers' tale er gengivet i Lecker Anzeiger, her citeret efter Hejmdal 29.5.1933.

61. Grænsevagten 1933, pp. 292-393. Auswärtiges Amt nr. 106 D 533722-533724 (RA). Hilke Lenzing: Die Deutsche Volksgruppe in Dänemark und das nationalsozialistische Deutschland, pp. 51-52 (Bonn 1973). Om Clausen Korffs rolle som grå eminence se pastor Schmidts vurdering heraf i Abt. $399.71 \mathrm{nr}$. 114, brev 11.12.1933 fra pastor Schmidt til Volksdeutsche Rat (S.H.L.). Sven Tägil tilslutter sig denne vurdering $i$ "Deutschland und die deutsche Minderheit in Nordschleswig « p. 46 (Stockholm 1970). Om Flensborg som ekspeditionskontor for NSAN se f.eks. Abt. $399.71 \mathrm{nr}$. 184 brev 1.10.1933 fra Clausen Korff til pastor Schmidt (S.-H-L.).

62. $\mathrm{N} X$ Harboe Kardel: 1. Tagebücher 5.5., 10.5., 20.5., 10.6. og 30.6.1933 (ADVN).

63. Deutscher Volkskalender für Nordschleswig 1934, p. 95. 61 Sti 1 Deutsche Stiftung nr. 21 384-385 (BP). Grænsevagten 1933 p. 356 . Ein Kampf um Nordschleswig, 5 Jahre NSAN, p. 40. N X Harboe Kardel: 1. Tagebücher 20.8.1933 (ADVN). Harboe Kardel: Grenzlandmelodie in Dur und Moll, p. 75. Det er således ikke rigtigt, når Japsen $\mathrm{i}$ "Å benrå bys historie " bd. III p. 191 henlægger NSAN's forste medlemsmade til den 19 . september 1933.

64. Aus der Geschichte der NSDAPN Kreis Tondern 1933-1943, pp. 8, 10-12, $16,19-20,24-36,38-39$.

65. Grænsevagten 1933 pp. 352-356.

66. Grænsevagten 1933 pp. 365, 397, 425426. N X Harboe Kardel: Tagebücher 
12.10.1933 (ADVN). Aus der Geschichte der NSDAPN Kreis Tondern 1933-1943, p. 40.

67. Duplikeret skrivelse 23.9.1933 (Jep Schmidts privatarkiv).

68. 61 Sti 1 Deutsche Stiftung nr. 10 286289 (BP). Abt. 399.71 nr. 184 brev 1.10.1933 fra Clausen Korff til pastor Schmidt med "Entschliessung" (S.H.L.). Med hensyn til pastor Schmidts opfattelse af grænserevisionskravet se H. Becker-Christensen op.cit. II pp. 269- 281.

69. Auswärtiges Amt nr. 113 D $649089-$ 649100 (RA).

70. Abt. $399.71 \mathrm{nr} .73$ brev $31.10 .1933 \mathrm{fra}$ Ernst Schröder til pastor Schmidt (S.H.L.)
71. Hejmdal 16.10.1933.

72. Auswärtiges Amt nr. 118 D 649871649873 (RA).

73. N X Harboe Kardel: 1. Tagebücher 10.8.1933 (ADVN). 61 Sti 1 Deutsche Stiftung nr. 1358345 (BP).

74. Hejmdal 13.10.1933. Deutscher Volkskalender für Nordschleswig 1934 p. 96. Ibid. 1935 p. 96 . Aus der Geschichte der NSDAPN Kreis Tondern 19331943, p. 51. Åbenrå bys historie, III pp. 191-192. Se også Nina Jacobsen: Tysk nazistisk ungdomsarbejde i Nordslesvig 1933-1945, Sønderjyske Årbøger 1996 pp. 195ff.

75. 61 Sti 1 Deutsche Stiftung, Nordschleswig nr. 22261. 